\title{
Cardiovascular health effects of oral and pulmonary exposure to multi-walled carbon nanotubes in ApoE-deficient mice
}

\author{
Christophersen, Daniel V.; Jacobsen, Nicklas R.; Andersen, Maria H. G.; Connell, Shea P.; Barfod, \\ Kenneth K.; Thomsen, Morten B.; Miller, Mark R.; Duffin, Rodger; Lykkesfeldt, Jens; Vogel, Ulla Birgitte \\ Total number of authors:
} 14

Published in:

Toxicology

Link to article, DOI:

10.1016/j.tox.2016.10.003

Publication date:

2016

Document Version

Peer reviewed version

Link back to DTU Orbit

Citation (APA):

Christophersen, D. V., Jacobsen, N. R., Andersen, M. H. G., Connell, S. P., Barfod, K. K., Thomsen, M. B., Miller, M. R., Duffin, R., Lykkesfeldt, J., Vogel, U. B., Wallin, H., Loft, S., Roursgaard, M., \& Møller, P. (2016). Cardiovascular health effects of oral and pulmonary exposure to multi-walled carbon nanotubes in ApoEdeficient mice. Toxicology, 371, 29-40. https://doi.org/10.1016/j.tox.2016.10.003

\section{General rights}

Copyright and moral rights for the publications made accessible in the public portal are retained by the authors and/or other copyright owners and it is a condition of accessing publications that users recognise and abide by the legal requirements associated with these rights.

- Users may download and print one copy of any publication from the public portal for the purpose of private study or research.

- You may not further distribute the material or use it for any profit-making activity or commercial gain

- You may freely distribute the URL identifying the publication in the public portal 
Cardiovascular health effects of oral and pulmonary exposure to multi-walled carbon nanotubes in ApoE-deficient mice

Daniel V. Christophersen ${ }^{\mathrm{a}}$, Nicklas R. Jacobsen ${ }^{\mathrm{b}}$, Maria H. G. Andersen ${ }^{\mathrm{a}}$, Shea P. Connell ${ }^{\mathrm{c}}$, Kenneth K. Barfod ${ }^{b}$, Morten B. Thomsen ${ }^{\mathrm{d}}$, Mark R. Miller ${ }^{\mathrm{c}}$, Rodger Duffin ${ }^{\mathrm{e}}$, Jens Lykkesfeldt ${ }^{\mathrm{f}}$, Ulla Vogel ${ }^{\mathrm{b}}$, g, Håkan Wallin ${ }^{\mathrm{a}, \mathrm{b}}$, Steffen Loft ${ }^{\mathrm{a}}$, Martin Roursgaard ${ }^{\mathrm{a}}$, Peter Møller $^{\mathrm{a}^{*}}$

aDepartment of Public Health, Section of Environmental Health, University of Copenhagen, Øster Farimagsgade 5A, DK-1014 Copenhagen K, Denmark.

${ }^{\mathrm{b}}$ The National Research Centre for the Working Environment, Lers $\varnothing$ Parkalle 105, 2100 Copenhagen, Denmark.

${ }^{c}$ Centre for Cardiovascular Science, University of Edinburgh, Edinburgh, United Kingdom. ${ }^{\mathrm{d} D e p a r t m e n t}$ of Biomedical Sciences, Heart and Circulatory Research Section, Faculty of Health Sciences, University of Copenhagen, Blegdamsvej 3 Building 12.5, DK-2200 Copenhagen N, Denmark.

${ }^{\mathrm{e}} \mathrm{MRC} /$ University of Edinburgh, Centre for Inflammation Research, Edinburgh, United Kingdom. fDepartment of Veterinary Disease Biology, Faculty of Health and Medical Sciences, University of Copenhagen, Ridebanevej 9, DK1870 Frederiksberg C, Denmark.

'Department of Micro- and Nanotechnology, Technical University of Denmark, DK-2800 Kgs. Lyngby, Denmark.

* Corresponding author: Department of Public Health, Section of Environmental Health, University of Copenhagen, Øster Farimagsgade 5A, DK-1014 Copenhagen K, Denmark, email: Pemo@sund.ku.dk

Running title: Cardiovascular effects after exposure to MWCNTs 


\title{
Highlights
}

- $A p o E^{-/-}$mice was exposed to MWCNT-7 by oral gavage or intratracheal instillation.

- Pulmonary exposure was associated with oxidative damage to DNA in lung tissue.

- Oral exposure did not affect the composition of the gut microbiome.

- The exposure was not associated with accelerated atherosclerosis in aorta or BCA.

- There was increased outer and inner aortic diameter in MWCNT exposed mice.

\begin{abstract}
Exposure to high aspect ratio nanomaterials, such as multi-walled carbon nanotubes (MWCNTs) may be associated with increased risk of atherosclerosis, pulmonary disease, and cancer. In the present study, we investigated the cardiovascular and pulmonary health effects of 10 weeks of repeated oral or pulmonary exposures to MWCNTs (4 or $40 \mu \mathrm{g}$ each week) in Apolipoprotein E-deficient (ApoE ${ }^{-/-}$ ) mice fed a Western-type diet. Intratracheal instillation of MWCNTs was associated with oxidative damage to DNA in lung tissue and elevated levels of lipid peroxidation products in plasma, whereas the exposure only caused a modest pulmonary inflammation in terms of increased numbers of lymphocytes in bronchoalveolar lavage fluid. Ultrasound imaging in live animals revealed an increase in the inner and outer wall thickness of the aortic arch at 10 weeks after pulmonary exposure to MWCNTs, which may suggest artery remodelling. However, we did not find accelerated plaque progression in the aorta or the brachiocephalic artery by histopathology. Furthermore, repeated oral exposure to MWCNTs did not cause changes in the composition of gut microbiota of exposed mice. Collectively, this study indicates that repeated pulmonary exposure to MWCNTs was associated with oxidative stress, whereas cardiovascular effects encompassed remodelling of the aorta wall.
\end{abstract}


Keywords: Apolipoprotein E-deficient mice, Carbon nanotubes, DNA strand breaks, Genotoxicity, Mitsui XNRI-7 CNT, Microbiome

\section{Introduction}

Multi-walled carbon nanotubes (MWCNTs) are fibres with high strength, making them attractive components in products that are designed to resist force. However, MWCNTs have a high aspect ratio, similar to asbestos, which may pose a public health threat because of hazards related to pulmonary inflammatory diseases, cardiovascular diseases and cancer. There are numerous types of MWCNTs, but Mitsui MWCNT XNRI-7 (hereafter referred to as "MWCNT-7”) has attracted special attention because it has been shown to cause mesothelioma in wild-type rats and a susceptible mouse model (Mercer et al. 2013b; Sakamoto et al. 2009; Takagi et al. 2008, 2012). Based on sufficient evidence from experimental animal models, MWCNT -7 was recently classified as possibly carcinogenic to humans (Group 2B) by the International Agency for Research on Cancer (IARC), whereas other types of CNTs were not classifiable due to limited data (Grosse et al. 2014). It has been shown that asbestos workers have increased cardiovascular disease mortality (Harding et al. 2012). Exposure to other high-aspect ratio materials, such as MWCNTs may pose the same hazard on the cardiovascular system. Atherosclerosis is a progressive disease of the vascular tree, characterized by the accumulation of lipids in the intima of medium and large sized arteries (Libby 2002). Secretion of pro-inflammatory cytokines initiates the expression of vascular adhesion molecules on the surface of endothelial cells in the artery lumen, which facilitates the migration of monocytes and leukocytes into the intima layer. Monocytes in the intima increase their uptake of oxidized lipids and oxidized low-density lipoprotein (oxLDL), which mediates transformation into lipid-laden macrophages and 
foam cells — the hallmark of the early stage of atherosclerosis. In vitro experiments have shown that MWCNTs promote these effects on endothelial cell activation and lipid accumulation in monocytederived foam cells (Cao et al. 2014, 2016). Progression of atherosclerosis leads to atheromas with a complex phenotype that eventually can develop into an unstable plaque with a thin fibrous cap, necrotic core, and neovascularization, which is associated with increased risk of plaque rupture, thrombus formation, and death in humans (Hansson and Libby 2006).

Only a few studies have investigated the pro-atherogenic effects of pulmonary exposure to CNTs. One study on administered single-walled CNTs (SWCNTs) by oropharyngeal aspiration, 20 $\mu \mathrm{g} / \mathrm{mouse}$ every other week for eight weeks, showed accelerated plaque progression and expression of vascular cellular adhesion molecule 1 (VCAM-1) in apolipoprotein E-deficient (ApoE ${ }^{-/}$) mice on a high-fat diet (Li et al. 2007b). Pulmonary exposure to MWCNTs (25.6 $\mu \mathrm{g} /$ mouse weekly) for five weeks caused pulmonary inflammation and accelerated plaque progression in Western-type diet fed $A p o E^{-/}$mice at day one after the last exposure (Cao et al. 2014). However, another study showed that pulmonary exposure to MWCNTs, $40 \mu \mathrm{g}$ /mouse twice a week for 16 weeks, caused a substantial pulmonary inflammation without accelerating plaque progression in $A p o E^{-/-}$mice on a high-fat diet (Han et al. 2015). Furthermore, a single pulmonary exposure to MWCNT-7 or two other MWCNTs (NRCWE 026 and NM-401) showed substantial lung inflammation and increased levels of the acute phase protein Serum Amyloid A that is suggested to be associated with accelerated atherosclerosis via modifications of high density lipoprotein-mediated cholesterol retrograde transport (Poulsen et al. 2015; Saber et al. 2014) .

Oral delivery of nanomaterials may occur intentionally or accidentally through ingestion of food, cosmetics or drugs (Duncan 2011; Frohlich and Roblegg 2012; Pele et al. 2015; Weir et al. 2012). Additionally, inhalation of particulate matter, but also nanomaterials including CNTs leads to oral uptake through mucociliary clearance (Oberdörster et al. 2002). Although other types of carbon-based 
nanomaterials such as carbon black is associated with altered vasomotor function in the aorta (Folkmann et al. 2012), no studies have yet investigated vascular effects after oral exposure to CNTs. Several studies have indicated that an altered gut microbiota can be associated with traits of the metabolic syndrome, including obesity and insulin resistance that are both associated with atherosclerosis (Cani et al. 2008; Tremaroli and Backhed 2012). Moreover, the same phylotypes of bacteria have been observed in the oral cavity, gut, and atheromas of patients with atherosclerosis, suggesting an infestation of external bacteria to the systemic circulation (Koren et al. 2011). This is supported by observations that treatment with broad spectrum antibiotics alters the composition of the gut microbiota and has a beneficial effect on plaque progression in $A p o E^{-/-}$mice (Rune et al. 2016). Furthermore, CNTs have an antimicrobial activity to commensal bacteria in the human gastrointestinal tract in vitro (Chen et al. 2013a; Zhu et al. 2014). It is currently unknown if in vivo exposure to CNTs influences the gut microbiota in mice. Interestingly, lipopolysaccharide (LPS) induced pulmonary inflammation is associated with altered gut microbiota (Sze et al. 2014).

The aim of this study was to investigate if repeated pulmonary or oral exposures to MWCNTs could lead to accelerated plaque progression in $A p o E^{-/-}$mice fed a Western-type diet. Pulmonary inflammation was assessed as the influx of neutrophils in bronchoalveolar lavage (BAL) fluid. Also, we assessed the bacterial composition of the gut microbiota after oral exposure to MWCNTs. Lipid peroxidation was measured in plasma as a marker of systemic oxidative stress, relevant for atherosclerosis. Finally, we investigated levels of oxidatively damaged DNA in lung tissue as both a marker of genotoxicity and oxidative stress.

\section{Methods}

\subsection{Animals and housing conditions}

Female C57BL/6-Ntac mice were used in a pilot study on pulmonary effects of different dispersants. The mice were purchased from Taconic (Ejby, Denmark) and given one week of acclimation before 
the first exposure at 8 weeks of age. For oral and pulmonary exposure to MWCNTs, female C57BL/6Apoe $^{\mathrm{tm} 1 \mathrm{Unc}} \mathrm{N} 11\left(\mathrm{ApoE}^{-/-}\right)$mice were purchased from Taconic (Ejby, Denmark) and given two weeks of acclimation before the first exposure at 10 weeks of age. All mice were assigned to groups of 5 mice and housed in polypropylene cages (Jeluxyl HW 300/500) with sawdust bedding and enrichment, such as pinewood sticks and rodent tunnels. The mice were maintained in a 12:12 $\mathrm{h}$. light-dark cycle with controlled humidity and temperature. All cages were sanitized once a week. Mice of the dispersant pilot study had ad libitum access to regular mouse chow (Altromin no. 1324, Christian Petersen, Denmark) and tap water. The $\mathrm{ApoE}^{-/-}$mice of the oral and pulmonary study were switched from regular chow to ad libitum access to Western Diet (21\% milk fat [w/w], $0.21 \%$ cholesterol [w/w]; Open Source Diets, RD Western Diet Product \# D12079B) two weeks prior the first exposure. The studies and all animal procedures were approved by the local animal ethical committee as well as the Danish Animal Experimental Inspectorate under the Ministry of Food, Agriculture and Fisheries (permission 2010/561-1779 and 2013-15-2934-00762).

\subsection{Chemicals}

Mitsui XNRI-7 MWCNT (MWCNT-7) was obtained as a gift from Mitsui \& Co, LTD (now produced by Hodagaya, Yokohama, Japan). Chemical composition and dimensions have been published previously. Briefly, median length and width were 3.86-5.7 $\mu \mathrm{m}$ and 49-74 $\mathrm{nm}$, respectively. The carbon purity was very high (>99\%) with almost none $(0.78 \%)$ of 31 tested metal impurities; these were mainly $\mathrm{Na}(0.41 \%)$ and $\mathrm{Fe}(0.32 \%)$ (Jackson et al. 2015; Poulsen et al. 2015). Endotoxins were below the level of detection. BET surface area was $26 \mathrm{~m}^{2} / \mathrm{g}$ (Jackson et al. 2015; Porter et al. 2010). Alveofact surfactant $(5 \mathrm{mg} / \mathrm{ml})$ was a kind gift provided by Lyomark Pharma (Lyomark Pharma, GmbH, Germany). D- $\alpha$-Phosphatidylcholine, dipalmitoyl (DPPC), Pluronic F-68, Pluronic F-127, sodium carboxymethylcellulose $\left(\mathrm{M}_{\mathrm{w}} \sim 90,000(\mathrm{CMC} 90 \mathrm{~K})\right)$, sodium carboxymethylcellulose $\left(\mathrm{M}_{\mathrm{w}}\right.$ 700,000 (CMC 700K)) and Tween 80 were purchased from Sigma-Aldrich, Denmark. Tween 20 
was obtained from Calbiochem, USA. Mouse serum was obtained under sterile conditions (obtained from C57BL/6 mice, purchased from Taconic, Denmark).

\subsection{Preparation of MWCNT-7 suspension and particle size determined by dynamic light} scattering

The quality of the dispersion of MWCNT-7 was determined by visual assessment and by dynamic light scattering (DLS) in sonicated vehicles with the following dispersants: Alveofact, DPPC, $2 \%$ mouse serum, Pluronic F-68, Pluronic F-127, CMC 90K, CMC 700K, Tween 20, and Tween 80. Vehicle stock preparations (1\% [W/W]) was made for Pluronic F-68, Pluronic F-127, CMC 90K, CMC 700K, Tween 20 and Tween 80 in nanopure water $(<45 \mu \mathrm{m}$ pore size $)$ on a magnetic stirrer until fully dissolved. DPPC 1\% stock was made dissolving DPPC in nanopure water followed by sonication for $30 \mathrm{sec}$ at $10 \%$ amplitude using a Branson Sonifier S-450D (Branson Ultrasonics Corp., Danbury, CT, USA) equipped with a disruptor horn (Model number: 101-147-037).

All $1 \%$ vehicle stock solutions were diluted to $0.1 \%$ and $0.01 \%$ in nanopure water and for Alveofact ( $5 \mathrm{mg} / \mathrm{ml}$ ) diluted to $1 \mathrm{mg} / \mathrm{ml}$ and $0.5 \mathrm{mg} / \mathrm{ml}$. MWCNT-7 was suspended in the $1 \%, 0.1 \%$ and $0.01 \%$ or $5 \mathrm{mg} / \mathrm{ml}, 1 \mathrm{mg} / \mathrm{ml}$ and $0.5 \mathrm{mg} / \mathrm{ml}$ vehical solutions to a MWCNTs concentration of $2.56 \mathrm{mg} / \mathrm{ml}$ and sonicated in an ice bath for 16 min with $10 \%$ amplitude using a Branson Sonifier S-450D (Branson Ultrasonics Corp., Danbury, CT, USA) equipped with a disruptor horn (Model number: 101-147-037).

DLS (Zetasizer Nano ZS, Malvern Instruments Ltd., UK) was used to measure the hydrodynamic size number distribution of the MWCNTs in the vehicles as described previously (Kyjovska et al. 2015). Calculations were done by the Dispersion Technology Software (DTS) using the absorbance and refractive index of Printex 90 (carbon black) and the viscosity of water, except for the CMC 90K (used in in vivo pilot study). As CMC90K is a highly viscous solution, we measured the viscosity of 
$1 \%, 0.1 \%$ and $0.01 \%$ solutions (without MWCNTs) at $25^{\circ} \mathrm{C}$ using a Vibro Viscometer ((SV-10, 0.3 10.000mPa*s) A\&D company, Limited N92 (u0013)) and RSVICO software (ver.1.11V A\&D company Limited). Dynamic viscosity was calculated as (measured viscosity/density) and used for calculations with the DTS software.

\subsection{Study design}

\subsubsection{Testing of dispersants for pulmonary inflammation (pilot study)}

MWCNTs are notoriously difficult to suspend in aqueous media without addition of a dispersant, but this artificial compound may have biological effects. Therefore, a panel of dispersants was initially tested for their ability to disperse MWCNTs without causing in vivo toxicity. The purpose of the pilot study was to find a suitable dispersant that 1) could disperse the MWCNTs, and 2) induced little pulmonary inflammation after repeated i.t. instillation. Wild-type C57BL/6 mice were i.t. instilled once a week for 4 weeks (i.e. 4 i.t. instillations in total) with Tween $20(0.1 \%)$, Tween $80(0.1 \%)$, CMC 90K (0.1\%), Alveofact $(5 \mathrm{mg} / \mathrm{ml})$ or mouse serum $(2 \%)$ (n=3/group). The exposure to Alveofact $(5 \mathrm{mg} / \mathrm{ml})$ and serum (2\%) group was repeated (identical setup) in a second trial, which also included nanopure water as a negative control ( $\mathrm{n}=3$ /group). The mice were euthanized at $24 \mathrm{~h}$ after the last exposure and the BAL fluid was collected.

\subsubsection{Oral or pulmonary exposure to MWCNTs (main study)}

$A p o E^{-/-}$mice were exposed to MWCNTs either by i.t. instillation or oral gavage. To be able to compare the MWCNTs doses given either via i.t. instillation or oral gavage all mice received a dosevolume of $50 \mu \mathrm{l}$ suspensions. Mice exposed to the same dose, but via a different route of administration, received a bolus from the same batch preparation at the given day. The doses were selected to be similar to previous exposures to CNTs that have used $25.6 \mu \mathrm{g} /$ mouse per week for 5 weeks (total dose $=128 \mu \mathrm{g} /$ mouse) (Cao et al. 2014) and $20 \mu \mathrm{g} /$ mouse once every other week for 8 weeks (total dose $=80 \mu \mathrm{g} /$ mouse) ( $\mathrm{Li}$ et al. 2007b). The exposure time was increased in the present 
study in an attempt to a more advanced progression of atherosclerosis as compared to previous studies on CNTs. The mice were exposed to MWCNTs once a week for 10 weeks to $4 \mu \mathrm{g}$ (total dose $40 \mu \mathrm{g}$ ) or $40 \mu \mathrm{g}$ (total dose $400 \mu \mathrm{g})(\mathrm{n}=10 \mathrm{mice} /$ group$)$. The weekly doses correspond to 0.16 or $1.6 \mathrm{mg} / \mathrm{kg}$ bodyweight, assuming mice weight $25 \mathrm{~g}$. These doses would be achieved in humans within a full week occupational exposure at 0.22 and $2.2 \mathrm{mg} / \mathrm{m}^{3}$, assuming complete deposition of MWCNTs in the airways, $70 \mathrm{~kg}$ bodyweight, inhalation of $10 \mathrm{~m}^{3}$ air/day and 5 working days/week. Three groups of $A p o E^{-/}$mice were i.t. instilled with either vehicle ( $0.1 \%$ Tween 80 in nanopure water), low (in total $40 \mu \mathrm{g}$ ), or high (in total $400 \mu \mathrm{g}$ ) dose of MWCNTs. Three groups of $A p o E^{-/-}$mice were orally exposed to vehicle $(0.1 \%$ Tween 80 in nanopure water), low (in total $40 \mu \mathrm{g}$ ), or high (in total $400 \mu \mathrm{g}$ ) dose of MWCNTs using oral gavage. All mice were euthanized $24 \mathrm{~h}$ after the last exposure.

For the oral gavage, mice were restrained by one hand, and $50 \mu 1$ suspensions were administered into the mice using an SGE glass syringe (250F-LT-GT, Trajan Scientific Australia Pty Ltd) equipped with a disposable polyurethane feeding needle (Fuchigami, Japan). After gavage, the mice were weighed and transferred back to their cage.

The i.t. instillation was carried out as described previously (Jacobsen et al. 2015). Briefly, the mice were anesthetized using 3-4\% isoflurane until fully relaxed. Hereafter they were transferred back down to a $50^{\circ}$ instillation board. A diode light source was positioned outside the larynx to visualize the epiglottis, trachea, and vocal cords. The tongue was gently pressed towards the lower jaw using a small spatula, and the trachea was intubated using a 24 gauge BD Insyte catheter (Ref: 381212, Becton Dickinson, Denmark) with a shortened needle. To ensure that the tube was positioned correctly in the trachea an extremely sensitive pressure transducer was used to measure the mouse respiration frequency as described previously (Jacobsen et al. 2009). Fifty microliters of dispersion were instilled immediately followed by $200 \mu \mathrm{l}$ air using a $250 \mu \mathrm{l}$ SGE glass syringe (250F-LT-GT, Trajan Scientific 
Australia Pty Ltd). After instillation, the mice were weighed and when fully conscious transferred back to their cages.

\subsection{Bronchoalveolar lavage and isolation of organs}

All mice were euthanized by a subcutaneous injection of Hypnorm /Midazolam, (2 Water: 1 Hypnorm: 1 Midazolam $(5 \mathrm{mg} / \mathrm{ml})$ ). The weight of each mouse was recorded and blood collected by cardiac puncture in an eppendorf tube containing $36 \mu \mathrm{K}_{2}$ EDTA. Blood was instantly centrifuged, and plasma immediately collected. BAL was performed by cannulating the trachea using a 22 gauge needle equipped with polyurethane catheter. The lungs were flushed twice using $(2 \times 0.8 \mathrm{ml} / \mathrm{mouse}$ ) physiological saline. Each flush consisted of one slowly down and up movement using a $1 \mathrm{ml}$ disposable syringe. The total BAL fluid volume recovery was estimated to be around $75 \%$ of the total flush volume. The BAL fluid was kept on ice (less than $1 \mathrm{~h}$ ) until it was centrifuged at $400 \mathrm{~g}$ at $4{ }^{\circ} \mathrm{C}$ for $10 \mathrm{~min}$ and, the supernatant stored at $-80^{\circ}$ until use.

The BAL pellet was resuspended in $100 \mu 1$ medium (HAMS F12 (GIBCO \#21765) supplemented with $10 \%$ foetal bovine serum (FBS)). The total BAL cell count from each mouse was determined using 40 $\mu \mathrm{l}$ cell suspension in an NC-100 Nucleocounter (ChemoMetec A/S, Denmark). To prepare Cytospin slides cells were centrifuged at $1000 \mathrm{rpm}$ for $4 \mathrm{~min}$. The objective slides containing cells from BAL fluid were stained using May-Grunwald/Giemsa co-staining. Differential cell count was performed by counting 200 cells per slide by a person blinded to the exposure groups.

Immediately after the BAL procedure, tissues were harvested. Lung tissues were dissected, snap frozen in liquid nitrogen and stored at $-80^{\circ} \mathrm{C}$. Pellets of mouse faeces were obtained aseptically from the descending colon, and frozen on dry ice and stored at $-80^{\circ} \mathrm{C}$. The heart and the whole aorta (from the arch to the iliac bifurcation) were carefully dissected and transferred to a petri dish containing oxygenated ice-cold Physiological Saline Solution (PSS) buffer. The aortic arch and brachiocephalic 
artery (BCA) were gently trimmed for fat- and connective tissue under an Olympus SZX7 stereomicroscope. Hereafter, the BCA was embedded in Tissue-Tek O.C.T ${ }^{\text {TM }}$ Compound (Sakura Finetek, Værløse, Denmark), frozen on dry ice and stored at $-80^{\circ} \mathrm{C}$. The heart and aorta were kept in cold PSS at $4^{\circ} \mathrm{C}$ until trimming.

\subsection{Atherosclerotic burden in the aorta and the brachiocephalic artery}

Atherosclerotic plaque progression was investigated non-invasively in real-time using ultrasound imaging and post-mortem by histopathological staining, and by en face analysis.

\subsubsection{Ultrasound imaging of the aortic arch}

High frequent ultrasound imaging of the aortic arch was used as a non-invasive method for evaluating the continuous development of atherosclerotic lesions in the aorta of $A p o E^{-/}$mice. Mice were anesthetized with $2 \%$ isoflurane and placed in supine position on a heating pad during the scanning. Temperature, heart rate, and respiration were closely monitored. The fur on the chest was gently removed using a hair removal cream (Veet, Reckitt Benckiser Group plc, United Kingdom) and aquasonic gel (Maersk-Andersen, Denmark) was applied to the chest for optimal contact between the scan head and the skin. Ultrasound imaging was performed using the Vevo 770 system (VisualSonics, Canada) equipped with the $40 \mathrm{MHz}$ RMV-704 scan head. Imaging was performed in the long-axis view using M-mode with the scan head fixed in the VisualSonics Vevo Integrated Rail System II. To ensure reproducibility and accuracy of each scan, the BCA was used as an anatomical landmark and scanning of the aortic arch was preformed at a depth of $5-6 \mathrm{~mm}$. The thickness of the aortic outer wall (i.e. superior curvature of the aortic arch), the inner wall (i.e. inferior curvature of the aortic arch) and lumen diameter were obtained from the ultrasound scanning. Supplementary Figure 3 shows the location of the aortic outer and inner wall. After scanning the mouse was allowed to recover fully from anaesthesia before being transferred back to its cage. 


\subsubsection{En face analysis on the whole aorta}

The heart and the aorta were placed in ice-cold oxygenated PSS buffer where fat- and connectivetissue were carefully removed using micro scissors under an Olympus SZX7 stereomicroscope. The trimmed aorta was cut longitudinally from the arch to the iliac artery, and then flattened and mounted between an objective glass and a cover slide, avoiding any overlapping tissue. Digital images of the intimal surface were obtained using an Olympus SZX7 stereomicroscope and Olympus Color View I camera. Atherosclerotic plaque burden was quantified as the percentage of lesions covering the intima surface area of the aorta and quantified by a person blinded to the exposure groups. Data analysis was carried out using ImageJ software.

\subsubsection{Atherosclerotic burden in the brachiocephalic artery}

The atherosclerotic burden in the BCA was assessed through the method of Miller et al. 2013. Briefly, BCAs were defrosted into formalin and lightly stained in acid fuschin prior to embedding in paraffin wax to aid the correct orientation of the vessel. Histological sections ( $5 \mu \mathrm{m}$ thick) of the BCA (a branch of the aortic arch to the carotid-subclavian bifurcation) were taken in quadruplicate at $100 \mu \mathrm{m}$ intervals, Sections were stained with Masson's Trichrome. The cross-sectional area of the plaque of a single replicate at each $100 \mu \mathrm{m}$ interval (beginning at the first section of an artery with a fully intact media) was measured and standardized to the medial area. A single mean value of atherosclerotic burden for each animal was calculated from the plaque size from each complete serial section throughout the BCA.

\subsection{DNA damage in lungs}

The level of oxidatively damaged DNA was measured by the comet assay as described previously (Danielsen et al. 2010). In brief, lung tissue was squeezed through a mess in a stainless steel cylinder with ice-cold Merchant's buffer, with a plunger and suspensions were then embedded in $0.75 \%$ 
agarose on gel bonds and lysed overnight in lysis solution $(2.5 \mathrm{M} \mathrm{NaCl}, 100 \mathrm{mM} \mathrm{Na} 2 \mathrm{EDTA}, 10 \mathrm{mM}$ Trizma base, $\mathrm{pH} 10.0$ ). Thereafter, they were washed $3 \times 5 \mathrm{~min}$ in a buffer (40 mM HEPES, $0.1 \mathrm{M}$ $\mathrm{KCl}, 0.5 \mathrm{mM} \mathrm{Na} 2 \mathrm{EDTA}, 200 \mu \mathrm{g} / \mathrm{ml} \mathrm{BSA}, \mathrm{pH}$ 8.0). Formamidopyrimidine DNA glycosylase (FPG) or human oxoguanine DNA glycosylase 1 (hOGG1) were added to the relevant gel bonds and incubated for $45 \mathrm{~min}$ at $37^{\circ} \mathrm{C}$. FPG was a gift from Professor Andrew Collins (University of Oslo, Norway). The hOGG1 enzyme was obtained from New England Biolabs (Ipswich, MA, USA). The gel bonds were then rinsed with cold milipore water and transferred to alkaline solution for 40 min ( $1 \mathrm{mM} \mathrm{Na} 2$ EDTA, $300 \mathrm{mM} \mathrm{NaOH}, \mathrm{pH}>13.0$ ) and were subsequently subjected to electrophoresis for $20 \mathrm{~min}$ in the same buffer at $300 \mathrm{~mA}$ and $0.83 \mathrm{~V} / \mathrm{cm}$ (from anode to cathode). After electrophoresis, gel bonds were washed $15 \mathrm{~min}$ in neutralization buffer (0.4 M Trizma base, $\mathrm{pH}$ 7.5), rinsed with water and immersed in $96 \%$ ethanol overnight. Gel bonds were air-dried, stained with YOYO-1 (Molecular Probes, Eugene, OR, USA) and visually scored in a blinded fashion. The levels of DNA damage were obtained by scoring 100 nuclei/gel in 2 gels. We used a five-class scoring system and transformed to lesions $/ 10^{6} \mathrm{bp}$ with a calibration curve where one arbitrary unit corresponds to 0.0273 lesions $/ 10^{6}$ bp (Forchhammer et al. 2010). The level of FPG or hOGG1 sensitive sites was calculated as the difference in DNA damage between slides that had been treated with the FPG or hOGG1 and buffer. We used Ro19-8022 and light exposed monocytic THP-1 cells as reference controls, which has been used as a control in comet assay validation trials (Ersson et al. 2013; Forchhammer et al. 2012; Johansson et al. 2010). Ro19-8022 was a gift from F. Hoffmann-La Roche (Basel, Switzerland).

\subsection{Malondialdehyde (MDA) levels in plasma}

As a marker of systemic oxidative stress, we measured the lipid peroxidation as MDA in plasma of $A p o E^{-/-}$mice using high-performance liquid chromatography (HPLC) with fluorescence detection as described previously (Lykkesfeldt 2001). All analyses were run in triplicates. 


\subsection{Gut microbiota}

DNA was extracted from frozen faecal samples from mice orally exposed to vehicle or $400 \mu \mathrm{g}$ MWCNTs using Qiagen, DNA Mini Stool kit (Qiagen, Ab, Sollentuna, Sweden) for detection of pathogens in frozen stool samples, with minor modifications as described previously (Barfod et al. 2013). We included an extraction contamination control, by performing mock extractions on our vehicle (0.1\% Tween 80 in nanopure water). The DGGE-PCR amplifying the V2-V3 region of the 16S ribosomal DNA gene of the bacteria was amplified by universal primer HDA1 and HDA2. The primer set HDA 1-GCf: (5'-ACT CCT ACG GGA GGC AGC AGT-`3) and HDA 2r (5'-GTA TTA CCG CGG CTG CTG GCA C-`3). The forward primer HDA 1-GCf: was labeled at the 5' end with a GC clamp (5'-CGC CCG GGG CGC GCC CCG GGC GGG GCG GGG GCA CGG GGG -3’)’' (Licht et al. 2006). Total PCR volume of $50 \mu$ l contained: $4 \mu 1$ Milli-Q water, $20 \mu 1$ of 5 PRIME Mastermix (MasterMix-100Rxns, 5PRIME GmbH, Hamburg), $8 \mu$ l of primer HDA 1f, $8 \mu$ l of primer HDA $2 r$, and finally $10 \mu \mathrm{l}$ of DNA template (approximately $16 \mathrm{ng} / \mu \mathrm{l}$ ). The PCR was performed under the following conditions: denaturing was carried out at $94^{\circ} \mathrm{C}$ for $4 \mathrm{~min}$, followed by the denaturing step $94^{\circ} \mathrm{C}$ for $30 \mathrm{sec}$, and then 30 cycles with annealing step at " $56^{\circ} \mathrm{C}$ for $30 \mathrm{sec}$, extension at $68^{\circ} \mathrm{C}$ for $60 \mathrm{sec}$, and the final extension step performed at $68^{\circ} \mathrm{C}$ for $7 \mathrm{~min}$. The PCR fragments were separated by DGGE as described with minor modifications including 3 lanes of marker and loading one no template PCR control per run along with the vehicle controls (Muyzer et al. 1993; Smith et al. 2011). Gels were run at $60^{\circ} \mathrm{C}$ for $16 \mathrm{~h}$ at a constant voltage of $70 \mathrm{~V}$ in $0.5 \times \mathrm{TAE}$ buffer and stained with Gel-Red (Thermo Scientific, Copenhagen, Denmark) for 60 min and photographed on the Gel Doc system (Biorad Laboratories AB, Solna, Sweden).

Analysis of the DGGE was performed blinded using BioNumerics Version 7.5 (Applied Maths NV, Sint-Martens-Latem, Belgium). After normalization, a band matching was performed with a tolerance 
of $1 \%$ and an optimization of $1 \%$. The results from the automatic band matching were checked manually and corrected where necessary. The similarity between profiles was calculated with a ranked Pearson correlation coefficient based on the band matching results using band intensities. A dendrogram was then constructed with Unweighted Pair Group Method with Arithmetic Mean (UPGMA). The reliability of the dendrogram (i.e. separated branches) was determined with the cophenetic correlation coefficient (Sokal and Rohlf 1962).

\subsection{Statistics}

The results were analysed by hierarchical nested ANOVA with a dose of MWCNTs nested in the route of exposure. Results on ultrasound scanning data were analysed by repeated measurements ANOVA. Main study results on BAL fluid cell counts did not have homogeneity of variance (assessed by Bartlett's test). Nevertheless, the reported statistical results correspond to parametric tests because this analysis gave similar results as non-parametric ANOVA tests. Differences between groups in post-hoc tests were assessed by Fisher's least significant difference (LSD) test. BCA atherosclerotic burden was analysed with Student's t-test using Welch's correction for unequal variances. Plasma MDA and genotoxicity in lung tissue were analysed by one-way ANOVA with post-hoc LSD test. Gut microbiota statistical analyzes were performed after mean-based normalization of profiles using Student's t-test. All results are reported as mean and standard error of the mean (SEM). Statistical significance was accepted at 5\% level. The statistical analysis was carried out in Statistica version 5.5 (StatSoft, Tulsa, OK, USA) and GraphPad Prism version 5.00 for Windows (GraphPad Software, San Diego, CA, USA).

\section{Results}

\subsection{Selection of a dispersant for MWCNT-7}

We tested a panel of dispersants in different concentrations $(0.01 \%, 0.1 \%$, and $1 \%$ solution) for dispersion of MWCNTs. DLS supplemented with macroscopic evaluation was used to assess the 
quality of the dispersion. Dispersants tested were Alveofact, CMC 90K, CMC 700K, DPPC, mouse serum, nanopure water, Pluronic F-68, Pluronic F-127, Tween 20 and Tween 80. Four dispersants (CMC 700K, DPPC, Pluronic and F-68, Pluronic F-127) were discarded due to poor dispersion (fluctuating count rate, wide size number distribution, and a Poly-Dispersity Index (PDI) above 0.5, bad macroscopic appearance, and a tendency to form large agglomerates of MWCNTs as indicated by DLS (data not shown). The remaining dispersants were screened in vivo for possible unwanted pulmonary inflammation. Pulmonary inflammation measured as the influx of neutrophils in BAL fluid was assessed after 4 i.t. instillations over a period of 4 weeks (Table 1). As we only wanted to investigate qualitatively the inflammatory response of each dispersant against the control group, not compare quantitatively responses by statistical tests, we used few mice per group. No p-values are reported for the pilot study because the low number of animals per group might be associated with a high risk of statistical type 2 error. Direct comparison of absolute or relative values of cell influx in BALF between the 4 and 10 weeks studies has not been done because the observations stem from different mice strains fed different diets. Additionally, it should be noted that none of the vehicles used in the present study were tested for being free of pathogens or pyrogen. The instillations of all types of dispersants were associated with influx of cells in BAL fluid as compared to nanopure water. Only one of the tested dispersants (Alveofact $(5 \mathrm{mg} / \mathrm{ml})$ ) caused a moderate influx of neutrophils in BAL fluid (5\% of the total cell number). The instillation of CMC 90K, serum, Tween 20, and Tween 80 had an influx of $\sim 0-3 \%$ of the total cell number. The dispersants' ability to cause influx of eosinophils in BAL fluid was as follows in descending order of percentage of total cells: Alveofact $(5 \mathrm{mg} / \mathrm{ml})<\operatorname{serum}(2 \%)<$ Tween $80<$ Tween $20<$ CMC $90 \mathrm{~K}<$ nanopure water.

Among the tested dispersants, $0.1 \%$ Tween 80 was chosen as being the most suitable dispersion of MWCNTs because it had a very stable count rate, a PDI of 0.3 , and a unimodal size number distribution (agglomeration size peak at $295 \mathrm{~nm}$ ). Supplementary Figure 1 shows size number 
distribution curve of $0.1 \%$ Tween 80 , and the visual appearance of MWCNT-7s $(2.56 \mathrm{mg} / \mathrm{ml})$ in $0.1 \%$ Tween 80 after sonication. In addition, i.t. instillation of Tween 80 was only associated with a modest influx of neutrophils in BAL fluid, which is supported by observations from other researchers who have used Tween 80 for i.t. instillation and have not observed signs of toxicity in rodents (Li et al. 2007a; Morimoto et al. 2010; Reddy et al. 2012). Instillation of Tween 80 was associated with a modest influx of eosinophils in BALF; however, this is very unlikely to have affected the MWCNTinduced vascular effects given that our previous study showned no association between high levels of eosiniphils and progression of atherosclerosis in $A p o E^{-/-}$mice (Cao et al. 2014). Also, we did not observe any changes in the breathing pattern of the mice after exposure to any of the dispersants.

\subsection{Assessment of pulmonary inflammation after exposure to MWCNTs}

The results on BAL fluid cell counts in MWCNT-exposed mice are reported in Table 2. I.t. instillation of vehicle was associated with increased levels of total cells $(\mathrm{P}<0.001)$, macrophages $(\mathrm{P}<0.001)$, neutrophils $(\mathrm{P}<0.001)$, lymphocytes $(\mathrm{P}<0.001)$ and eosinophils $(\mathrm{P}<0.001)$ compared to dosing vehicle by oral gavage. There was a higher number of lymphocytes in BAL fluid following i.t. instillation in the highest MWCNT-exposure group $(\mathrm{P}<0.05)$. Similar increases were observed for neutrophils $(\mathrm{P}=0.08)$ and macrophages $(\mathrm{P}=0.23)$, although they did not reach statistical significance. The number of eosinophils was decreased after i.t. exposure to $40 \mu \mathrm{g}(\mathrm{P}<0.01)$ and $400 \mu \mathrm{g}(\mathrm{P}<$ 0.001) of MWCNTs compared to vehicle exposures.

The oral exposure to $400 \mu \mathrm{g}$ MWCNTs significantly increased the influx of neutrophils in BAL fluid (P < 0.05), although the actual number was small (net increase of $400 \pm 200$ cells) (Table 2). There were unaltered and low numbers of total cells, macrophages, lymphocytes or eosinophils in the BAL fluid of mice exposed to MWCNTs by oral gavage.

\subsection{DNA damage in lung tissue after i.t. instillation of MWCNT-7}


Fig 1 shows the levels of DNA damage in lung tissue following pulmonary MWCNTs exposure. In general, there seemed to be increased levels of oxidatively damaged DNA in all MWCNT-exposed groups, although there only was statistical significance in hOGG1-sensitive sites $(\mathrm{P}<0.05)$ at 40 $\mu \mathrm{g} / \mathrm{mouse}$ and in FPG-sensitive sites at $400 \mu \mathrm{g} / \mathrm{mouse}(\mathrm{P}<0.05)$. A pooled analysis of FPG- and hOGG1-sensitive sites, using standardized results, showed increased level of oxidatively damaged DNA in lung tissue in the group with $40 \mu \mathrm{g}$ /mouse $(1.58 \pm 0.11$ fold, $\mathrm{N}=10, \mathrm{P}<0.05)$ and 400 $\mu \mathrm{g} /$ mouse $(1.51 \pm 0.14$ fold $, \mathrm{N}=10, \mathrm{P}<0.05)$ as compared to the control group $(1.0 \pm 0.14$ fold, $\mathrm{N}=$ 10) (Supplementary Table 1 describes the standardization). There was no difference in the level of DNA strand breaks in lung tissue between the groups of mice after i.t. instillation of MWCNTs, although there was a tendency toward an inverse dose-response relationship. The levels of SB, hOGG1- and FPG-sensitive sites in the Ro19-8022 control samples were $0.27 \pm 0.03,0.32 \pm 0.04$ and $0.95 \pm 0.15$ lesions $/ 10^{6}$ base pairs, respectively $(n=5)$.

\subsection{Malondialdehyde levels in plasma of MWCNT-7 exposed mice}

Pulmonary exposure to $40 \mu \mathrm{g}$ MWCNTs increased MDA plasma concentrations as compared to the control group $(\mathrm{P}<0.05)$. However, there was no difference between the group exposed to $400 \mu \mathrm{g}$ MWCNTs and control group (Fig 2). The oral exposure to $400 \mu \mathrm{g}$ MWCNTs decreased MDA plasma concentration compared to the control group $(\mathrm{P}<0.01)$, with no effect observed by exposure to 40 $\mu \mathrm{g}$ MWCNTs.

\subsection{Gut microbiota after oral exposure to MWCNT-7}

Supplementary Fig 2 shows the microbial diversity in the gut between mice that received vehicle and MWCNTs $(400 \mu \mathrm{g})$ by oral gavage. The dendrogram and principal component analysis (PCA) plot showed no clear difference in internal bacterial clustering between samples within experimental groups. There was no statistically significant difference between the vehicle and MWCNT-exposed mice with respect to average species diversity and the average species evenness. 
3.6.Atherosclerotic burden in the aorta and the brachiocephalic artery of MWCNT-7 exposed mice

\subsubsection{Ultrasound imaging}

The results on ultrasound imaging (M-mode) of live animals are shown in Fig 3. There was a time-dependent gradual increase of aortic wall inner diameter within all the groups $(\mathrm{P}<0.001)$. There was a statistically significant interaction between the dose of MWCNTs and duration of exposure $(\mathrm{P}<0.05)$. The highest dose of MWCNTs by i.t. instillation was associated with a 1.36 fold increase (95\% CI: $1.21-1.51$ fold) of inner aortic diameter $(\mathrm{P}<0.001)$. Oral exposure to the highest MWCNTs dose was associated with a 1.15-fold increase (95\% CI: $1.01-1.28$ fold) in inner aortic diameter $(\mathrm{P}<0.05)$.

The outer diameter of the aorta increased in a time-dependent manner $(\mathrm{P}<0.001)$. There was a statistically significant interaction between the exposure route and dose of MWCNTs $(\mathrm{P}<0.05)$. The exposure to the highest dose of MWCNTs by i.t. instillation was associated with 1.43 fold (95\% CI: $1.13-1.63$ fold $)$ increased outer aortic diameter $(\mathrm{P}<0.001)$, whereas the oral exposure had no effect on the outer diameter of the aorta $(\mathrm{P}=0.82)$.

There were no time-related effects on the aorta lumen diameter $(\mathrm{P}=0.87)$. There were no differences between exposure groups with regard to MWCNTs exposure and route of administration $(\mathrm{P}=0.42)$.

\subsubsection{En face aorta}

The results on plaque progression, assessed by en face analysis, are shown in Fig 4. There were no differences between the groups with regard to the dose of MWCNTs $(\mathrm{P}=0.58)$.

\subsubsection{Histological analysis of BCA}

The exposure to the highest dose of MWCNTs ( $400 \mu \mathrm{g} / \mathrm{mouse})$ by either oral or pulmonary route had no significant effect on the atherosclerotic burden in the BCA - measured as a mean of serial sections (Fig 5). 


\section{Discussion}

The present study investigated the changes in arteries and pulmonary inflammation after multiple oral or pulmonary exposures to MWCNTs. In addition, we also investigated the composition of gut microbiota and pulmonary genotoxicity after oral or i.t. exposure to MWCNTs, respectively. Fig 6 depicts the relationship between biomarkers and pathways of cardiovascular effects in the present study. The available literature on cardiovascular effects of pulmonary exposure to MWCNTs is sparse, and there exists no published literature investigating the atherogenic effects of oral exposure to MWCNTs. In contrast, there is a large body of literature showing that pulmonary exposure to other nanomaterials and combustion-derived particulate matter is associated with accelerated atherosclerosis and vascular dysfunction (Møller et al. 2016). Similar effects on atherosclerosis and vascular dysfunction are observed across experimental models and humans after exposure to combustion-derived particulate matter (Møller et al. 2011). Studies on controlled exposure to nanomaterials in humans have not been launched because of the obvious health hazard.

Our findings show that repeated i.t. exposure to MWCNTs did not cause the expected and typical particle-driven pulmonary inflammation (i.e. increased total cell numbers and neutrophil influx in BAL fluid). However, the i.t. exposure to $400 \mu \mathrm{g}$ MWCNT-7 increased the number of lymphocytes in BAL fluid, which was accompanied by a modest increase in neutrophils. The exposure to both doses was associated with decreased number of eosinophils in BAL fluid, which is in keeping with previous observations after repeated exposure to MWCNTs (Cao et al. 2014). We had expected a much more pronounced influx of inflammatory cells in BAL fluid. Earlier studies of i.t. instillation of NM-401 MWCNTs (using $2 \%$ serum as dispersant), which are physic-chemically similar to MWCNT-7s, showed a predominant influx of neutrophils at $24 \mathrm{~h}$ post-exposure in mice (approximately $10^{5}$ cells after i.t. instillation of $54 \mu \mathrm{g} /$ mouse), whereas there were elevated levels of neutrophils, macrophages, and lymphocytes at day 28 after a single i.t. instillation (Poulsen et al. 
2015). Likewise, long-term inhalation exposure to MWCNT-7s in mice and rats has shown an influx of neutrophils in BAL fluid (Kasai et al. 2015; Porter et al. 2013). During the necropsy we visually detected (macroscopically) black material in the lung tissue of mice after exposure to MWCNT-7, indicating that rather large quantities of MWCNTs were still present in the lungs. In addition, MWCNT-7 is known to be biopersistent and have been detected in lung tissue and extrapulmonary tissues at long times after exposure (Mercer et al. 2013a). As others have observed a strong inflammatory response following a single instillation of the same material (MWCNT-7) (Porter et al. 2010; Poulsen et al. 2013) we speculate that the repeated i.t. instillations of the dispersant (i.e. $0.1 \%$ Tween 80) and the competing eosinophilia might have dampened the inflammatory response of MWCNT-7. It should be emphasized that a systematic review of literature indicates no consistent association between pulmonary inflammation and atherogenic changes in animal models after exposure to various types of combustion-derived nanoparticles or engineered nanomaterials (Møller et al. 2016). Furthermore, it has been shown that repeated i.t. instillations of lipopolysaccharide, once a week for 10 weeks, increased neutrophilic influx in BALF, without alteration to the extent of atherosclerosis in aorta and BCA (Christophersen et al. 2016). Thus, we feel it is unlikely that overt pulmonary inflammation is a pre-requisite for these cardiovascular effects in animal models. Unexpectedly, oral exposure to $400 \mu \mathrm{g}$ MWCNT-7 caused a small, but statistically significant, increase in the number of neutrophils in BAL fluid, which was not accompanied by similar increases in other types of leukocytes.

The pulmonary exposure to MWCNT-7 was associated with increased level of oxidatively damaged DNA in lung tissue. FPG and hOGG1 detect 8-oxoguanine and ring-opened formamidopyrimidine lesions (Cadet et al. 2012). These lesions may arise from reactive oxygen species, generated from exogenous (e.g. MWCNTs) or endogenous (e.g. inflammatory cells) sources. It has been shown that exposure to particulate matter is associated with elevated levels of oxidatively damaged DNA in lung 
tissue at doses that do not cause pulmonary overload (Møller et al. 2013). The elevated levels of DNA damage indicates a pro-oxidant environment in the lungs as well as a genotoxic hazard, which is in accordance with the observation of carcinogenicity after exposure to MWCNT-7 (Sakamoto et al. 2009; Takagi et al. 2008, 2012) and in agreement with previous studies reporting increased levels of DNA strand breaks following a single i.t. instillation of NM-401 and NRCWE-026 (Poulsen et al. 2015). There is surprisingly little information on genotoxicity endpoints of MWCNT-7, and this was one of the main reasons for classification as 'only possibly carcinogenic to humans' (Kuempel et al. 2016). The pro-oxidant status is also supported by observations of increased levels of MDA in plasma, suggesting systemic oxidative stress after i.t. exposure to $40 \mu \mathrm{g}$ MWCNT-7. The unaltered level of MDA at the high dose might be related to a scavenging effect of the MWCNTs, i.e. the MDA molecules might not translocate to the circulation because they bind to the MWCNTs in the lungs. Bell-shaped concentration curves have also been observed for ROS production by CNTs (Folkmann et al. 2008; Jacobsen et al. 2008). On the other hand, the decreased plasma MDA levels in the orally exposed mice should be interpreted with caution. The Western-type diet contains MDA and/or propenal-derivatives of MDA, which are bioavailable (Giron-Calle et al. 2002). Thus, MWCNTs in the gut may bind to MDA and inhibit its uptake, thereby reducing the plasma concentration of MDA. To the contrary, oral exposure to SWCNTs was associated with increased levels of oxidatively damaged DNA in the liver and lungs of rats (Folkmann et al. 2009).

The i.t. exposure to MWCNTs was associated with increased inner and outer wall thickness of the aortic arch. Similar effects were also observed in the orally exposed mice, although only reaching statistical significance for the inner wall thickness. Collectively, it suggests that exposure to MWCNTs is associated with increased thickness of the aorta wall, which does not appear to be directly linked to accelerated plaque progression. Increased wall thickness is normally related to remodelling of the artery wall - a well-known phenomenon of essential hypertension in humans, 
where intima-media thickness increases of $15-40 \%$ can occur without changes in lumen diameter (Laurent and Boutouyrie 2015). However, the obtained ultrasound images in mice do not have sufficient resolution to differentiate between the different layers of the aorta and measure intimamedia thickness. Nevertheless, outward remodelling of the aorta has been described as an agedependent effect in ApoE $E^{-/}$mice over a 6 months period (Bentzon et al. 2003). The radial enlargement of the arterial wall, with constant lumen size, suggests a pressure-driven remodelling of the aorta (Laurent and Boutouyrie 2015), although it should be noted that the majority of studies have shown that $A p o E^{-/-}$mice do not develop hypertension (Vasquez et al. 2012). The assessment of plaque composition in the BCA, a region of the artery under high wall stress, showed unaltered morphology or media-to-lumen ratio (results not shown). This indicates that outward remodelling is not a generalized tendency in the arterial tree of the MWCNT-exposed mice. The atherogenic effects found after exposure to CNTs have primarily been investigated in the aorta using en face analysis (Cao et al. 2014; Li et al. 2007b). It is possible to detect differences of a few percentages in absolute plaque size values with the en face analysis of aorta from this number of mice (Chen et al. 2013b; Mikkelsen et al. 2011). Thus, the modest difference in plaque area in the group of mice exposed to the highest dose of MWCNTs in the gastrointestinal tract as compared to controls (i.e. 10\% and 7\% aorta plaque area, respectively) is similar to differences that have been statistically significant in other studies. Studies on concentrated ambient air pollution particles have shown that ultrasound scanning provided reproducible results on the progression of atherosclerosis in the aorta (Chen et al. 2010; Sun et al. 2008). We also investigated the atherosclerotic burden in the BCA, which is a medium size artery which rapidly generates complex atherosclerotic plaques in high-fat-fed $A p o E^{-/-}$mice, the extent of which is increased after exposure to diesel exhaust particles (Miller et al. 2013) or SWCNTs (Li et al. 2007b). Investigating the plaque burden in serial histological sections of the BCA, we detected a relatively high plaque burden in all three groups of both i.t. instilled and oral gavaged mice; however, 
there was no statistically significant effect of exposure to MWCNTs. Overall, that data suggests that exposure to MWCNTs did not cause progression of atherosclerosis, whereas there were signs of outward remodelling in the aorta. The nature of bioactive factors, leading to outward remodelling, has not yet been elucidated. Interestingly, recent observations have shown that the serum from MWCNT-7 exposed mice contains bioactive factors that cause vasomotor dysfunction ex vivo when administered to aorta rings from unexposed mice (Aragon et al. 2016).

The gut microbiota has recently been considered to be important for the toxicological effects of nanomaterials (Pietroiusti et al. 2016). Here, we did not detect an alternation of the dominant gut microbial species in stools from Western-type diet fed $A p o E^{-/}$mice exposed orally to $400 \mu \mathrm{g}$ MWCNTs, using DGGE. DGGE is a fast method, however, it is neither quantitative nor provides any taxonomical information, which would be obtainable with $16 \mathrm{~S}$ rRNA gene sequencing. $16 \mathrm{~S}$ sequence analysis would also show changes in less abundant bacteria. Several in vitro studies have shown that CNTs may have an antimicrobial effect, that is influenced by the physicochemical properties such as length, diameter, and rigidity (Chen et al. 2013a), with SWCNTs showing more antimicrobial activity than MWCNTs (Zhu et al. 2014). We have previously shown that SWCNTs have a marginal effect on the lung microbiome (Barfod et al. 2015). We did not investigate the lung microbiome in the present study because there was no presence of pulmonary inflammation by the MWCNT exposure. A suggested mechanism for the antimicrobial effect in vitro is reactive oxygen species production by CNTs (Rajavel et al. 2013), although this remains to be confirmed in vivo.

In conclusion, the results of the present study show that exposure to MWCNT-7 is associated with elevated levels of oxidative stress biomarkers in lungs and plasma, whereas cardiovascular effects included increased aorta wall thickness. An increased aorta wall thickness without loss of lumen, suggesting vascular wall remodelling, is typically observed in essential hypertension, which is an independent risk factor for cardiovascular disease. 


\section{Conflict of interest}

The authors declared no conflict of interest.

\section{Funding}

The work was supported by the Danish Nanosafety Centre (grant no. 20110092173-3) from the Danish Working Environment Research Foundation.

\section{Acknowledgement}

The authors would like to thank Lisbeth Bille Carlsen, Joan Elizabeth Frandsen, Michael Guldbrandsen, Eva Terrida, Natascha Synnøve Olsen, Lourdes Pedersen and Anne-Karin Asp for their excellent technical assistance.

\section{References}

Aragon, M., Erdely, A., Bishop, L., Salmen, R., Weaver, J., Liu, J., Hall, P., Eye, T., Kodali, V., Zeidler-Erdely, P., Stafflinger, J.E., Ottens, A.K. and Campen, M.J. 2016. MMP-9-dependent serumborne bioactivity caused by multi-walled carbon nanotube exposure induces vascular dysfunction via the CD36 scavenger receptor. Toxicol Sci 150, 488-498.

Barfod, K.K., Roggenbuck, M., Hansen, L.H., Schjorring, S., Larsen, S.T., Sorensen, S.J. and Krogfelt, K.A. 2013. The murine lung microbiome in relation to the intestinal and vaginal bacterial communities. BMC microbiology 13, 303. 
Barfod, K.K., Vrankx, K., Mirsepasi-Lauridsen, H.C., Hansen, J.S., Hougaard, K.S., Larsen, S.T., Ouwenhand, A.C. and Krogfelt, K.A. 2015. The Murine Lung Microbiome Changes During Lung Inflammation and Intranasal Vancomycin Treatment. Open Microbiol. J 9, 167-179.

Bentzon, J.F., Pasterkamp, G. and Falk, E. 2003. Expansive remodeling is a response of the plaquerelated vessel wall in aortic roots of apoE-deficient mice: an experiment of nature. Arterioscler. Thromb. Vasc. Biol. 23, 257-262.

Cadet, J., Loft, S., Olinski, R., Evans, M.D., Bialkowski, K., Richard Wagner, J., Dedon, P.C., Møller, P., Greenberg, M.M. and Cooke, M.S. 2012. Biologically relevant oxidants and terminology, classification and nomenclature of oxidatively generated damage to nucleobases and 2-deoxyribose in nucleic acids. Free Radic. Res. 46, 367-381.

Cani, P.D., Bibiloni, R., Knauf, C., Waget, A., Neyrinck, A.M., Delzenne, N.M. and Burcelin, R. 2008. Changes in gut microbiota control metabolic endotoxemia-induced inflammation in high-fat diet-induced obesity and diabetes in mice. Diabetes 57, 1470-1481.

Cao, Y., Jacobsen, N.R., Danielsen, P.H., Lenz, A.G., Stoeger, T., Loft, S., Wallin, H., Roursgaard, M., Mikkelsen, L. and Møller, P. 2014. Vascular effects of multiwalled carbon nanotubes in dyslipidemic ApoE-/- mice and cultured endothelial cells. Toxicol. Sci. 138, 104-116.

Cao, Y., Roursgaard, M., Jacobsen, N.R., Møller, P. and Loft, S. 2016. Monocyte adhesion induced by multi-walled carbon nanotubes and palmitic acid in endothelial cells and alveolar-endothelial cocultures. Nanotoxicology 10, 235-244.

Chen, H., Wang, B., Gao, D., Guan, M., Zheng, L., Ouyang, H., Chai, Z., Zhao, Y. and Feng, W. 2013a. Broad-Spectrum Antibacterial Activity of Carbon Nanotubes to Human Gut Bacteria. Small 9, 2735-2746. 
Chen, L.C., Quan, C., Hwang, J.S., Jin, X., Li, Q., Zhong, M., Rajagopalan, S. and Sun, Q. 2010. Atherosclerosis lesion progression during inhalation exposure to environmental tobacco smoke: a comparison to concentrated ambient air fine particles exposure. Inhalation Toxicol. 22, 449-459.

Chen, T., Jia, G., Wei, Y. and Li, J. 2013b. Beijing ambient particle exposure accelerates atherosclerosis in ApoE knockout mice. Toxico. Lett. 223, 146-153.

Christophersen, D.V., Jacobsen, N.R., Jensen, D.M., Kermanizadeh, A., Sheykhzade, M., Loft, S., Vogel, U., Wallin, H. and Møller, P. 2016. Inflammation and Vascular Effects after Repeated Intratracheal Instillations of Carbon Black and Lipopolysaccharide. PLoS One 11, e0160731.

Danielsen, P.H., Loft, S., Jacobsen, N.R., Jensen, K.A., Autrup, H., Ravanat, J.L., Wallin, H. and Møller, P. 2010. Oxidative stress, inflammation, and DNA damage in rats after intratracheal instillation or oral exposure to ambient air and wood smoke particulate matter. Toxicol Sci 118, 574585.

Duncan, T.V. 2011. Applications of nanotechnology in food packaging and food safety: Barrier materials, antimicrobials and sensors. Journal of colloid and interface science 363, 1-24.

Ersson, C., Møller, P., Forchhammer, L., Loft, S., Azqueta, A., Godschalk, R.W., van Schooten, F.J., Jones, G.D., Higgins, J.A., Cooke, M.S., Mistry, V., Karbaschi, M., Phillips, D.H., Sozeri, O., Routledge, M.N., Nelson-Smith, K., Riso, P., Porrini, M., Matullo, G., Allione, A., Stepnik, M., Ferlinska, M., Teixeira, J.P., Costa, S., Corcuera, L.A., Lopez de Cerain, A., Laffon, B., Valdiglesias, V., Collins, A.R. and Möller, L. 2013. An ECVAG inter-laboratory validation study of the comet assay: inter-laboratory and intra-laboratory variations of DNA strand breaks and FPG-sensitive sites in human mononuclear cells. Mutagenesis 28, 279-286.

Folkmann, J.K., Risom, L., Jacobsen, N.R., Wallin, H., Loft, S. and Møller, P. 2009. Oxidatively damaged DNA in rats exposed by oral gavage to C60 fullerenes and single-walled carbon nanotubes. Environ. Health Perspect. 117, 703-708. 
Folkmann, J.K., Vesterdal, L.K., Sheykhzade, M., Loft, S. and Møller, P. 2012. Endothelial dysfunction in normal and prediabetic rats with metabolic syndrome exposed by oral gavage to carbon black nanoparticles. Toxicol Sci 129, 98-107.

Forchhammer, L., Ersson, C., Loft, S., Möller, L., Godschalk, R.W., van Schooten, F.J., Jones, G.D., Higgins, J.A., Cooke, M., Mistry, V., Karbaschi, M., Collins, A.R., Azqueta, A., Phillips, D.H., Sozeri, O., Routledge, M.N., Nelson-Smith, K., Riso, P., Porrini, M., Matullo, G., Allione, A., Stepnik, M., Komorowska, M., Teixeira, J.P., Costa, S., Corcuera, L.A., Lopez de Cerain, A., Laffon, B., Valdiglesias, V. and Møller, P. 2012. Inter-laboratory variation in DNA damage using a standard comet assay protocol. Mutagenesis 27, 665-672.

Forchhammer, L., Johansson, C., Loft, S., Möller, L., Godschalk, R.W., Langie, S.A., Jones, G.D., Kwok, R.W., Collins, A.R., Azqueta, A., Phillips, D.H., Sozeri, O., Stepnik, M., Palus, J., Vogel, U., Wallin, H., Routledge, M.N., Handforth, C., Allione, A., Matullo, G., Teixeira, J.P., Costa, S., Riso, P., Porrini, M. and Møller, P. 2010. Variation in the measurement of DNA damage by comet assay measured by the ECVAG inter-laboratory validation trial. Mutagenesis 25, 113-123.

Frohlich, E. and Roblegg, E. 2012. Models for oral uptake of nanoparticles in consumer products. Toxicology 291, 10-17.

Giron-Calle, J., Alaiz, M., Millan, F., Ruiz-Gutierrez, V. and Vioque, E. 2002. Bound malondialdehyde in foods: bioavailability of the N-2-propenals of lysine. J. Agric. Food Chem. 50, 6194-6198.

Grosse, Y., Loomis, D., Guyton, K.Z., Lauby-Secretan, B., El Ghissassi, F., Bouvard, V., BenbrahimTallaa, L., Guha, N., Scoccianti, C., Mattock, H. and Straif, K. 2014. Carcinogenicity of fluoroedenite, silicon carbide fibres and whiskers, and carbon nanotubes. Lancet Oncol. 15, 1427-1428. 
Han, S.G., Howatt, D., Daugherty, A. and Gairola, G. 2015. Pulmonary and atherogenic effects of multi-walled carbon nanotubes (MWCNT) in apolipoprotein-E-deficient mice. J. Toxicol. Environ. Health A 78, 244-253.

Hansson, G.K. and Libby, P. 2006. The immune response in atherosclerosis: a double-edged sword. Nat. Rev. Immunol. 6, 508-519.

Harding, A.H., Darnton, A. and Osman, J. 2012. Cardiovascular disease mortality among British asbestos workers (1971-2005). Occup. Environ. Med. 69, 417-421.

Jackson, P., Kling, K., Jensen, K.A., Clausen, P.A., Madsen, A.M., Wallin, H. and Vogel, U. 2015. Characterization of genotoxic response to 15 multiwalled carbon nanotubes with variable physicochemical properties including surface functionalizations in the FE1-Muta(TM) mouse lung epithelial cell line. Environ. Mo. Mutagen. 56, 183-203.

Jacobsen NR, Pojana G, White P, Møller P, Cohn CA, Korsholm KS, Vogel U, Marcomini A, Loft S and Wallin H. 2008. Genotoxicity, cytotoxicity, and reactive oxygen species induced by single-walled carbon nanotubes and $\mathrm{C}(60)$ fullerenes in the FE1-Mutatrade markMouse lung epithelial cells. Environ. Mol. Mutagen. 49, 476-487.

Jacobsen, N.R., Møller, P., Jensen, K.A., Vogel, U., Ladefoged, O., Loft, S. and Wallin, H. 2009. Lung inflammation and genotoxicity following pulmonary exposure to nanoparticles in ApoE-/mice. Part. Fibre Toxicol. 6, 2.

Jacobsen, N.R., Stoeger, T., van den Brule, S., Saber, A.T., Beyerle, A., Vietti, G., Mortensen, A., Szarek, J., Budtz, H.C., Kermanizadeh, A., Banerjee, A., Ercal, N., Vogel, U., Wallin, H. and Møller, P. 2015. Acute and subacute pulmonary toxicity and mortality in mice after intratracheal instillation of $\mathrm{ZnO}$ nanoparticles in three laboratories. Food Chem. Toxicol. 85, 84-95.

Johansson, C., Møller, P., Forchhammer, L., Loft, S., Godschalk, R.W., Langie, S.A., Lumeij, S., Jones, G.D., Kwok, R.W., Azqueta, A., Phillips, D.H., Sozeri, O., Routledge, M.N., Charlton, A.J., 
Riso, P., Porrini, M., Allione, A., Matullo, G., Palus, J., Stepnik, M., Collins, A.R. and Möller, L. 2010. An ECVAG trial on assessment of oxidative damage to DNA measured by the comet assay. Mutagenesis 25, 125-132.

Kasai, T., Umeda, Y., Ohnishi, M., Kondo, H., Takeuchi, T., Aiso, S., Nishizawa, T., Matsumoto, M. and Fukushima, S. 2015. Thirteen-week study of toxicity of fiber-like multi-walled carbon nanotubes with whole-body inhalation exposure in rats. Nanotoxicology 9, 413-422.

Koren, O., Spor, A., Felin, J., Fak, F., Stombaugh, J., Tremaroli, V., Behre, C.J., Knight, R., Fagerberg, B., Ley, R.E. and Backhed, F. 2011. Human oral, gut, and plaque microbiota in patients with atherosclerosis. Proc. Natl. Acad. Sci. U.S.A. 108 Suppl 1, 4592-4598.

Kuempel, E.D., Jaurand, M.C., Moller, P., Morimoto, Y., Kobayashi, N., Pinkerton, K.E., Sargent, L.M., Vermeulen, R.C., Fubini, B. and Kane, A.B. 2016. Evaluating the mechanistic evidence and key data gaps in assessing the potential carcinogenicity of carbon nanotubes and nanofibers in humans. Crit. Rev. Toxicol. 1-58.

Kyjovska, Z.O., Jacobsen, N.R., Saber, A.T., Bengtson, S., Jackson, P., Wallin, H. and Vogel, U. 2015. DNA strand breaks, acute phase response and inflammation following pulmonary exposure by instillation to the diesel exhaust particle NIST1650b in mice. Mutagenesis 30, 499-507.

Laurent, S. and Boutouyrie, P. 2015. The structural factor of hypertension: large and small artery alterations. Circ. Res. 116, 1007-1021.

Li, J.G., Li, W.X., Xu, J.Y., Cai, X.Q., Liu, R.L., Li, Y.J., Zhao, Q.F. and Li, Q.N. 2007a. Comparative study of pathological lesions induced by multiwalled carbon nanotubes in lungs of mice by intratracheal instillation and inhalation. Environ Toxicol 22, 415-421.

Li, Z., Hulderman, T., Salmen, R., Chapman, R., Leonard, S.S., Young, S.H., Shvedova, A., Luster, M.I. and Simeonova, P.P. 2007b. Cardiovascular effects of pulmonary exposure to single-wall carbon nanotubes. Environ. Health Perspect. 115, 377-382. 
Libby, P. 2002. Inflammation in atherosclerosis. Nature 420, 868-874.

Licht, T.R., Hansen, M., Poulsen, M. and Dragsted, L.O. 2006. Dietary carbohydrate source influences molecular fingerprints of the rat faecal microbiota. BMC Microbiology 6, 98.

Lykkesfeldt, J. 2001. Determination of malondialdehyde as dithiobarbituric acid adduct in biological samples by HPLC with fluorescence detection: comparison with ultraviolet-visible spectrophotometry. Clin. Chem. 47, 1725-1727.

Mercer, R.R., Scabilloni, J.F., Hubbs, A.F., Battelli, L.A., McKinney, W., Friend, S., Wolfarth, M.G., Andrew, M., Castranova, V. and Porter, D.W. 2013a. Distribution and fibrotic response following inhalation exposure to multi-walled carbon nanotubes. Part. Fibre Toxicol. 10, 33.

Mercer, R.R., Scabilloni, J.F., Hubbs, A.F., Wang, L., Battelli, L.A., McKinney, W., Castranova, V. and Porter, D.W. 2013b. Extrapulmonary transport of MWCNT following inhalation exposure. Part. Fibre Toxicol 10, 1.

Mikkelsen, L., Sheykhzade, M., Jensen, K.A., Saber, A.T., Jacobsen, N.R., Vogel, U., Wallin, H., Loft, S. and Møller, P. 2011. Modest effect on plaque progression and vasodilatory function in atherosclerosis-prone mice exposed to nanosized TiO2. Part. Fibre Toxicol 8, 1-17.

Miller, M.R., McLean, S.G., Duffin, R., Lawal, A.O., Araujo, J.A., Shaw, C.A., Mills, N.L., Donaldson, K., Newby, D.E. and Hadoke, P.W. 2013. Diesel exhaust particulate increases the size and complexity of lesions in atherosclerotic mice. Part. Fibre Toxicol. 10, 61.

Møller, P., Christophersen, D.V., Jacobsen, N.R., Skovmand, A., Gouveia, A.C., Andersen, M.H., Kermanizadeh, A., Jensen, D.M., Danielsen, P.H., Roursgaard, M., Jantzen, K. and Loft, S. 2016. Atherosclerosis and vasomotor dysfunction in arteries of animals after exposure to combustionderived particulate matter or nanomaterials. Crit. Rev. Toxicol. 46, 437-476.

Møller, P., Danielsen, P.H., Jantzen, K., Roursgaard, M. and Loft, S. 2013. Oxidatively damaged DNA in animals exposed to particles. Crit. Rev. Toxicol. 43, 96-118. 
Møller, P., Mikkelsen, L., Vesterdal, L.K., Folkmann, J.K., Forchhammer, L., Roursgaard, M., Danielsen, P.H. and Loft, S. 2011. Hazard identification of particulate matter on vasomotor dysfunction and progression of atherosclerosis. Crit. Rev. Toxicol. 41, 339-368.

Morimoto, Y., Hirohashi, M., Ogami, A., Oyabu, T., Myojo, T., Nishi, K.-i., Kadoya, C., Todoroki, M., Yamamoto, M. and Murakami, M. 2010. Inflammogenic effect of well-characterized fullerenes in inhalation and intratracheal instillation studies. Part. Fibre Toxicol. 7, 1.

Muyzer, G., de Waal, E.C. and Uitterlinden, A.G. 1993. Profiling of complex microbial populations by denaturing gradient gel electrophoresis analysis of polymerase chain reaction-amplified genes coding for 16S rRNA. Appl. Environ. Microbiol. 59, 695-700.

Oberdörster, G., Sharp, Z., Atudorei, V., Elder, A., Gelein, R., Lunts, A., Kreyling, W. and Cox, C. 2002. Extrapulmonary translocation of ultrafine carbon particles following whole-body inhalation exposure of rats. J. Toxicol. Environ. Health A 65, 1531-1543.

Pele, L.C., Thoree, V., Bruggraber, S.F., Koller, D., Thompson, R.P., Lomer, M.C. and Powell, J.J. 2015. Pharmaceutical/food grade titanium dioxide particles are absorbed into the bloodstream of human volunteers. Part. Fibre Toxicol 12, 26.

Pietroiusti, A., Magrini, A. and Campagnolo, L. 2016. New frontiers in nanotoxicology: Gut microbiota/microbiome-mediated effects of engineered nanomaterials. Toxicol. Appl. Pharmacol. 299, 90-95.

Porter, D.W., Hubbs, A.F., Chen, B.T., McKinney, W., Mercer, R.R., Wolfarth, M.G., Battelli, L., Wu, N., Sriram, K., Leonard, S., Andrew, M., Willard, P., Tsuruoka, S., Endo, M., Tsukada, T., Munekane, F., Frazer, D.G. and Castranova, V. 2013. Acute pulmonary dose-responses to inhaled multi-walled carbon nanotubes. Nanotoxicology 7, 1179-1194.

Porter, D.W., Hubbs, A.F., Mercer, R.R., Wu, N., Wolfarth, M.G., Sriram, K., Leonard, S., Battelli, L., Schwegler-Berry, D., Friend, S., Andrew, M., Chen, B.T., Tsuruoka, S., Endo, M. and Castranova, 
V. 2010. Mouse pulmonary dose- and time course-responses induced by exposure to multi-walled carbon nanotubes. Toxicology 269, 136-147.

Poulsen, S.S., Jacobsen, N.R., Labib, S., Wu, D., Husain, M., Williams, A., Bøgelund, J.P., Andersen, O., Købler, C. and Mølhave, K. 2013. Transcriptomic analysis reveals novel mechanistic insight into murine biological responses to multi-walled carbon nanotubes in lungs and cultured lung epithelial cells. PLoS One 8, e80452.

Poulsen, S.S., Saber, A.T., Williams, A., Andersen, O., Købler, C., Atluri, R., Pozzebon, M.E., Mucelli, S.P., Simion, M. and Rickerby, D. 2015. MWCNTs of different physicochemical properties cause similar inflammatory responses, but differences in transcriptional and histological markers of fibrosis in mouse lungs. Toxicol. Appl. Pharmacol. 284, 16-32.

Rajavel, K., Gomathi, R., Manian, S. and Rajendra Kumar, R.T. 2013. In vitro bacterial cytotoxicity of cnts: reactive oxygen species mediate cell damage edges over direct physical puncturing. Langmuir 30, 592-601.

Reddy, A., Reddy, Y.N., Krishna, D.R. and Himabindu, V. 2012. Pulmonary toxicity assessment of multiwalled carbon nanotubes in rats following intratracheal instillation. Environmen. Toxicol. 27, 211-219.

Rune, I., Rolin, B., Larsen, C., Nielsen, D.S., Kanter, J.E., Bornfeldt, K.E., Lykkesfeldt, J., Buschard, K., Kirk, R.K., Christoffersen, B., Fels, J.J., Josefsen, K., Kihl, P. and Hansen, A.K. 2016. Modulating the Gut Microbiota Improves Glucose Tolerance, Lipoprotein Profile and Atherosclerotic Plaque Development in ApoE-Deficient Mice. PLoS One 11, e0146439.

Saber, A.T., Jacobsen, N.R., Jackson, P., Poulsen, S.S., Kyjovska, Z.O., Halappanavar, S., Yauk, C.L., Wallin, H. and Vogel, U. 2014. Particle-induced pulmonary acute phase response may be the causal link between particle inhalation and cardiovascular disease. Wiley Interdiscip. Rev. Nanomed. Nanobiotechnol. 6, 517-531. 
Sakamoto, Y., Nakae, D., Fukumori, N., Tayama, K., Maekawa, A., Imai, K., Hirose, A., Nishimura, T., Ohashi, N. and Ogata, A. 2009. Induction of mesothelioma by a single intrascrotal administration of multi-wall carbon nanotube in intact male Fischer 344 rats. J. Toxicol. Sci. 34, 65-76.

Smith, B., Li, N., Andersen, A.S., Slotved, H.C. and Krogfelt, K.A. 2011. Optimising bacterial DNA extraction from faecal samples: comparison of three methods. Open Microbiol. J. 5, 14-17.

Sokal, R.R. and Rohlf, F.J. 1962. The comparison of dendrograms by objective methods. Taxon, 3340.

Sun, Q., Yue, P., Kirk, R.I., Wang, A., Moatti, D., Jin, X., Lu, B., Schecter, A.D., Lippmann, M., Gordon, T., Chen, L.C. and Rajagopalan, S. 2008. Ambient air particulate matter exposure and tissue factor expression in atherosclerosis. Inhal. Toxicol. 20, 127-137.

Sze, M.A., Tsuruta, M., Yang, S.W., Oh, Y., Man, S.F., Hogg, J.C. and Sin, D.D. 2014. Changes in the bacterial microbiota in gut, blood, and lungs following acute LPS instillation into mice lungs. PLoS One 9, e111228.

Takagi, A., Hirose, A., Futakuchi, M., Tsuda, H. and Kanno, J. 2012. Dose-dependent mesothelioma induction by intraperitoneal administration of multi-wall carbon nanotubes in p53 heterozygous mice. Cancer Sci. 103, 1440-1444.

Takagi, A., Hirose, A., Nishimura, T., Fukumori, N., Ogata, A., Ohashi, N., Kitajima, S. and Kanno, J. 2008. Induction of mesothelioma in p53+/- mouse by intraperitoneal application of multi-wall carbon nanotube. J. Toxicol. Sci. 33, 105-116.

Tremaroli, V. and Backhed, F. 2012. Functional interactions between the gut microbiota and host metabolism. Nature 489, 242-249.

Vasquez, E.C., Peotta, V.A., Gava, A.L., Pereira, T.M. and Meyrelles, S.S. 2012. Cardiac and vascular phenotypes in the apolipoprotein E-deficient mouse. J. Biomed. Sci. 19, 22. 
Weir, A., Westerhoff, P., Fabricius, L., Hristovski, K. and von Goetz, N. 2012. Titanium Dioxide Nanoparticles in Food and Personal Care Products. Environ. Sci. Technol. 46, 2242-2250.

Zhu, B., Xia, X., Xia, N., Zhang, S. and Guo, X. 2014. Modification of fatty acids in membranes of bacteria: implication for an adaptive mechanism to the toxicity of carbon nanotubes. Environ. Sci. Technol. 48, 4086-4095. 


\section{Legends to figures}

Fig 1. Levels of DNA damage in lung tissue after repeated exposure to MWCNT-7 by i.t. instillation. Each symbol represents DNA damage level in one mouse. Lines represent mean \pm SEM of 10 mice in each group. Statistical analyses were carried out using ANOVA.

Fig 2. Systemic lipid peroxidation measured as malondialdehyde (MDA) levels in plasma of $A p o E^{-/-}$ mice i.t. or oral exposed with vehicle, $40 \mu \mathrm{g}$ or $400 \mu \mathrm{g}$ MWCNT-7. Results are presented as mean \pm SEM. Statistical analyses were carried out using hierarchical nested ANOVA.

Fig 3. Ultrasound scanning of the aortic arch of anaesthetized $A p o E^{-/}$mice at 0,8 and 10 weeks of exposure to vehicle, $40 \mu \mathrm{g}$ and $400 \mu \mathrm{g}$ MWCNT-7 by i.t. instillation or oral administration. The measurements include the thickness of the inner wall (top), the outer wall (middle) and lumen diameter of the aortic arch. All measurements were obtained using M-mode view of the aortic arch with the brachiocephalic artery used as an anatomic landmark. Results are presented as mean \pm SEM. Each data point represents an individual mouse $(n=6-7)$. Statistical analyses were carried out using hierarchical nested ANOVA. Supplementary figure 3 depicts how the ultrasound imaging was performed.

Fig 4. Aorta plaque area ( $\%$ of intima surface area) in $A p o E^{-/-}$mice after i.t. or oral exposure to vehicle, $40 \mu \mathrm{g}$ or $400 \mu \mathrm{g}$ MWCNT-7 at 0,8 and 10 weeks. Results are presented as mean \pm SEM. Statistical analyses were carried out using hierarchical nested ANOVA. Supplementary figure 4 depicts images of the level of atherosclerotic plaques in the en face analysis.

Fig 5. Atherosclerotic plaque burden (average of serial sections throughout artery, standardized to the percentage of the area of the media layer of the blood vessel) in the brachiocephalic artery of $A p o E^{-/-}$mice after i.t. or oral exposures with vehicle or $400 \mu \mathrm{g}$ MWCNT-7 for 10 weeks. Results are presented as mean \pm SEM. Statistical analyses were performed by Student's t-test with Welch's correction for unequal variances. Supplementary figure 5 depicts images of the Masson's trichrome staining.

Fig. 6. Summary of biomarkers related to development of atherosclerosis in MWCNT-exposed mice. Bold arrows indicate pathways with statistically significant effect of investigated biomarker. 

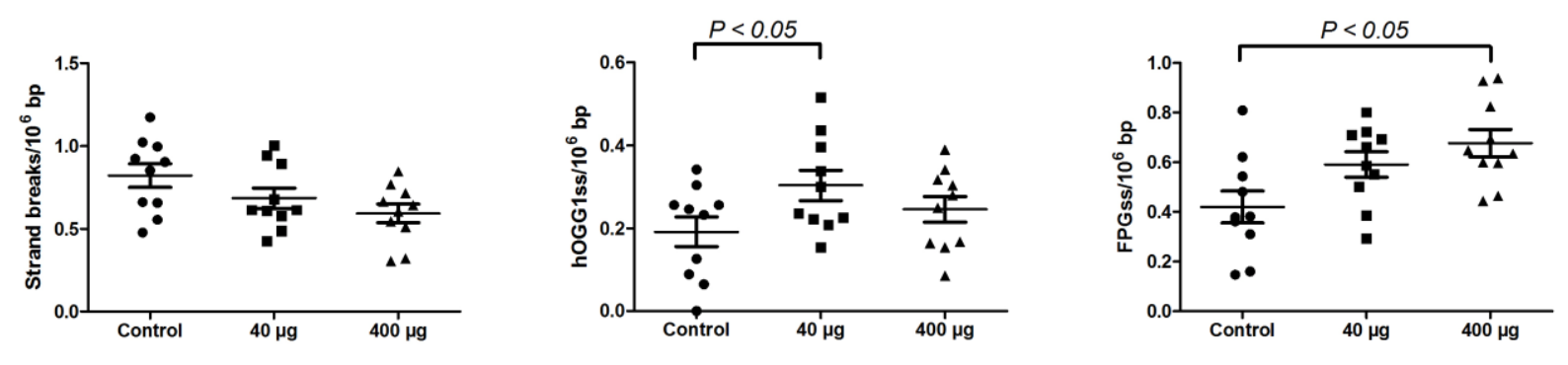

Fig 1

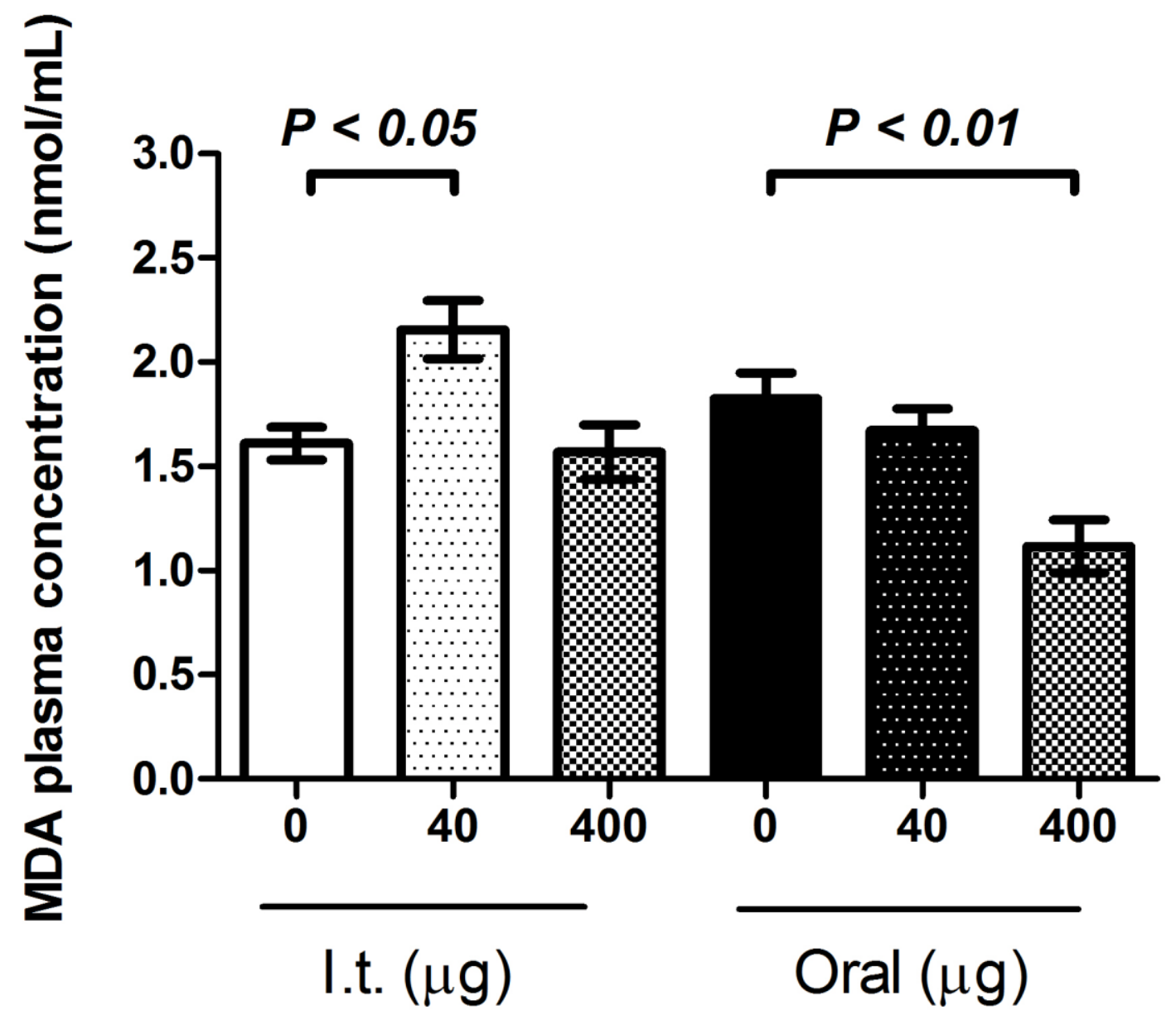

Fig 2 

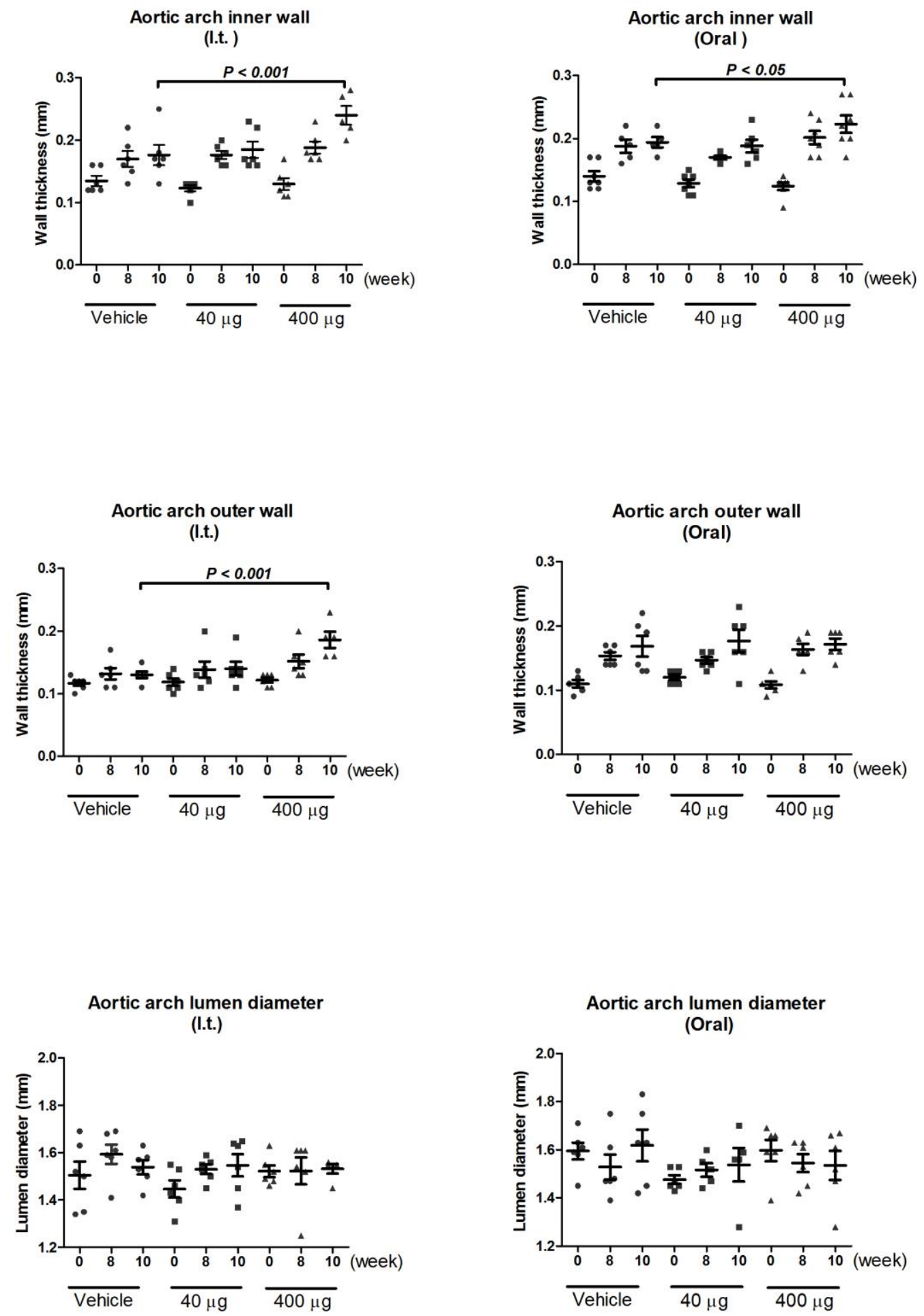

Fig 3 


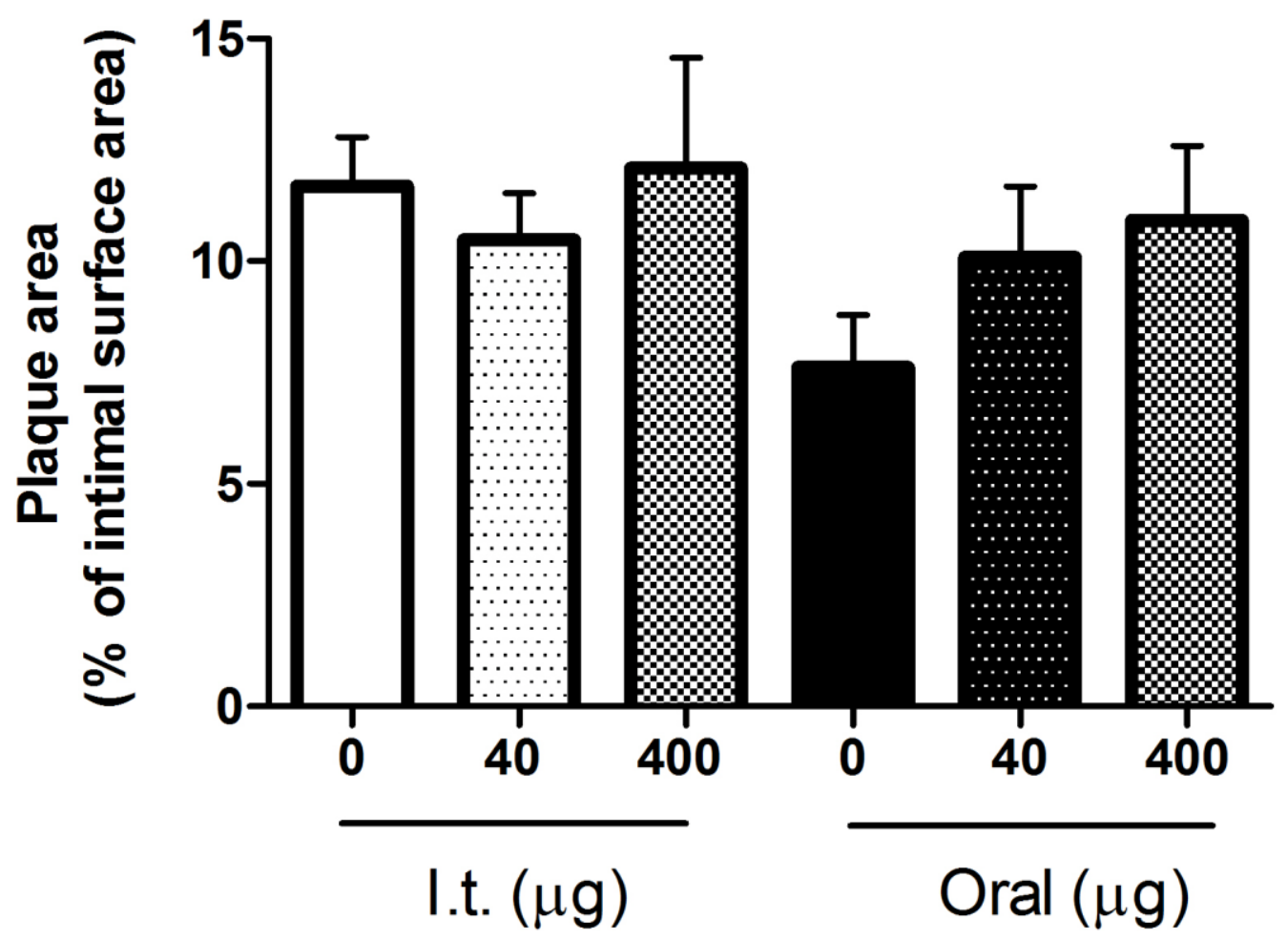

Fig 4 


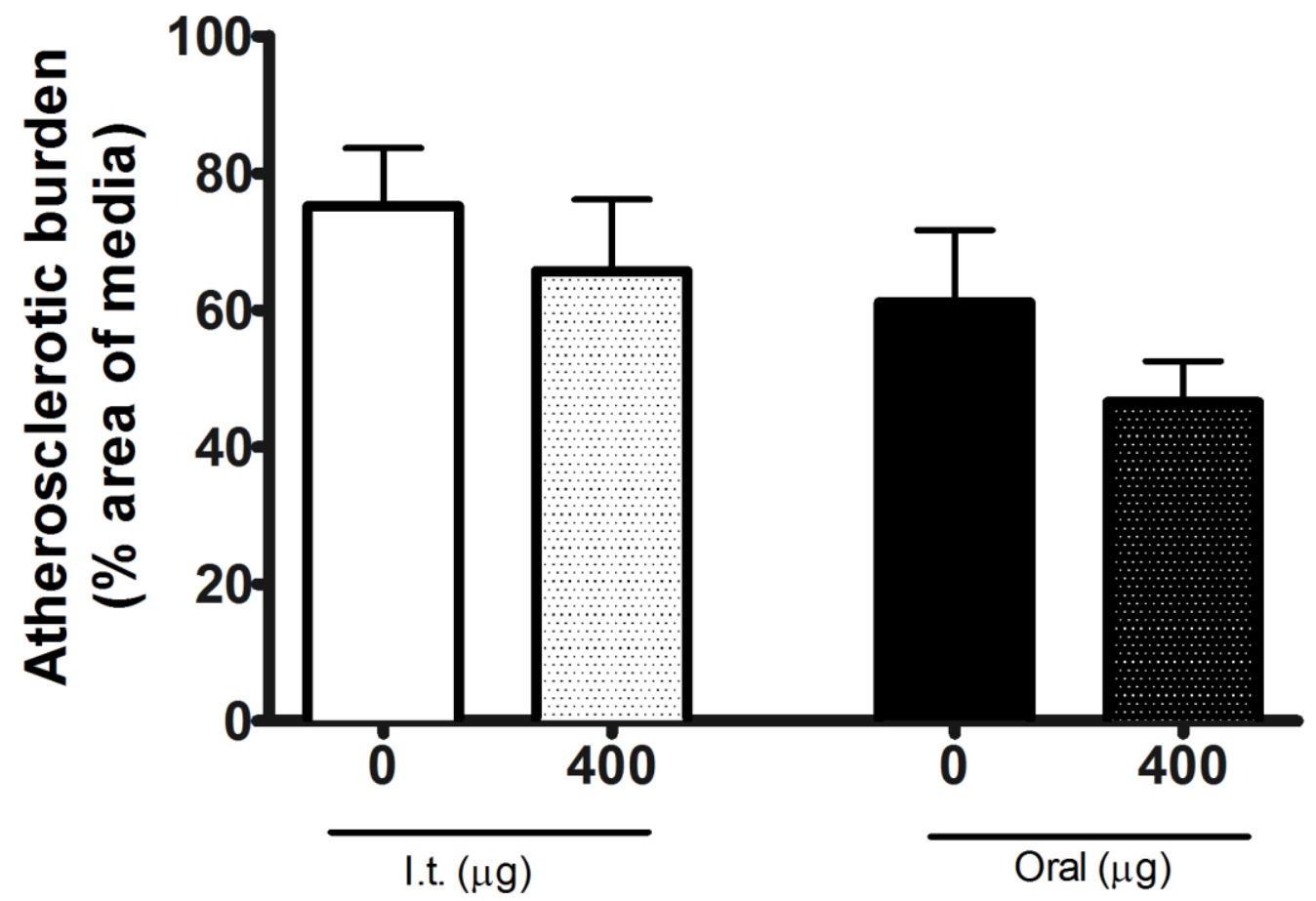

Fig 5 


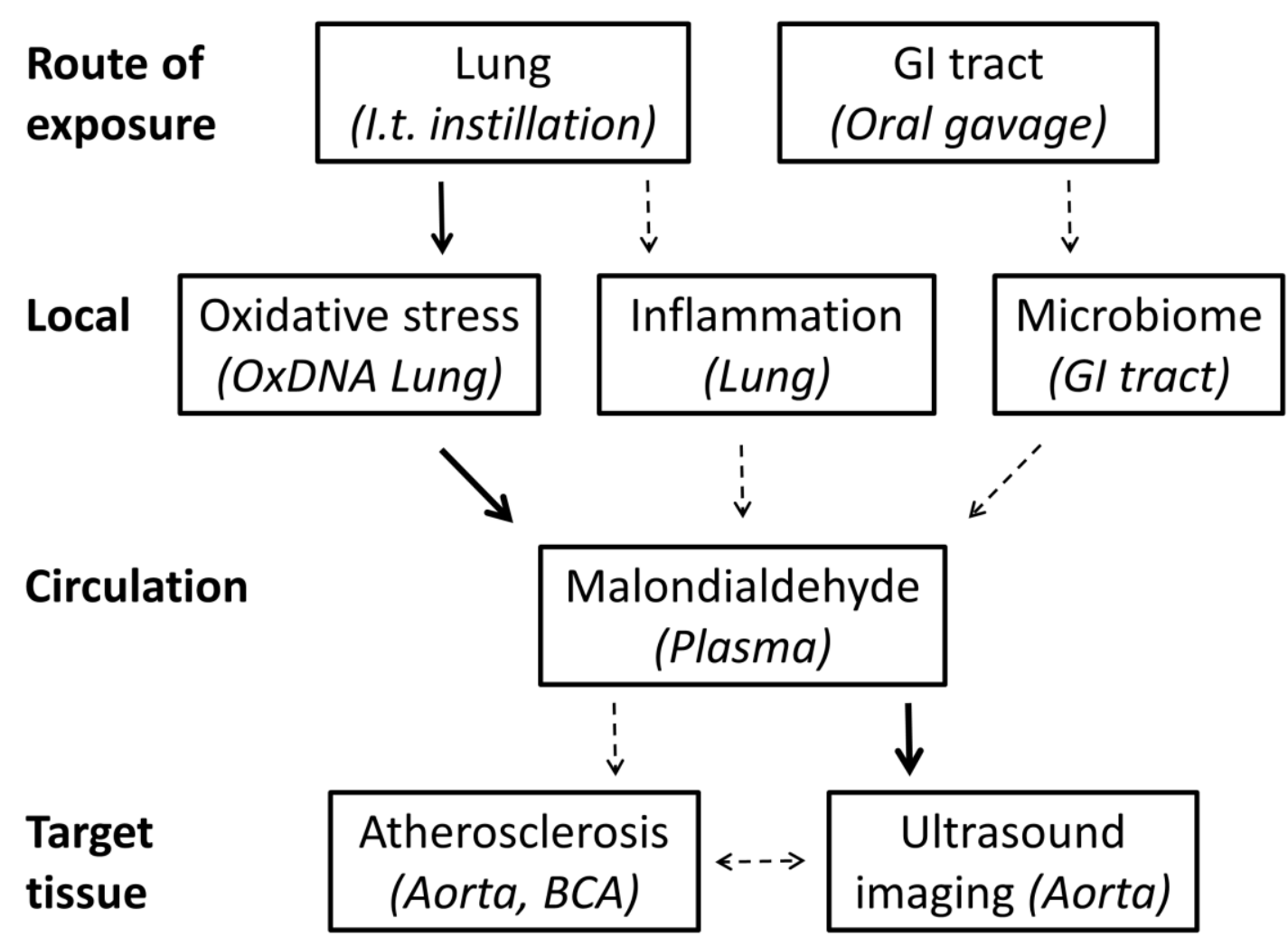

Fig 6 


\section{Table 1}

BAL fluid cell number 24 hours post-exposure to the last of 4 weekly instillations of vehicle with different dispersants

\begin{tabular}{|l|l|l|l|l|l|l|}
\hline Cell types & Tween $\mathbf{2 0}$ & Tween $\mathbf{8 0}$ & $\mathbf{C M C ~ 9 0 K}$ & Alveofact $\mathbf{( 5}$ & Serum & Nanopure \\
& $\mathbf{( 0 . 1 \% )}$ & $\mathbf{( 0 . 1 \% )}$ & $\mathbf{( 0 . 1 \% )}$ & $\mathbf{m g} / \mathbf{m l})$ & $\mathbf{( 2 \% )}$ & water \\
\hline Total cells & $139.3 \pm 12.8$ & $223.7 \pm 61.6$ & $159.3 \pm 11.3$ & $201.1 \pm 51.8$ & $92.8 \pm 27.2$ & $15.2 \pm 8.4$ \\
\hline Neutrophils & $1.5 \pm 1.1$ & $5.9 \pm 3.1$ & $1.1 \pm 3.1$ & $10.2 \pm 3.9$ & $1.7 \pm 1.0$ & $0.0 \pm 0.0$ \\
\hline Macrophages & $104.3 \pm 14.9$ & $133.7 \pm 35.1$ & $136.7 \pm 7.5$ & $80.7 \pm 16.3$ & $58.2 \pm 22.1$ & $13.2 \pm 7.2$ \\
\hline Eosinophils & $20.8 \pm 5.3$ & $65.6 \pm 29.5$ & $1.7 \pm 1.7$ & $93.3 \pm 41.4$ & $21.2 \pm 16.5$ & $0.0 \pm 0.0$ \\
\hline Lymphocytes & $3.1 \pm 2.1$ & $7.1 \pm 5.4$ & $8.5 \pm 4.8$ & $3.7 \pm 2.1$ & $3.9 \pm 1.2$ & $0.3 \pm 0.3$ \\
\hline Epithelial & $9.7 \pm 1.9$ & $11.5 \pm 4.0$ & $19.0 \pm 6.6$ & $13.3 \pm 6.0$ & $7.9 \pm 2.4$ & $1.7 \pm 1.4$ \\
\hline
\end{tabular}

C57BL/6 mice received a total of 4 i.t. instillations with vehicle once a week for 4 weeks $(\mathrm{n}=3$ mice/group), except for Alveofact and serum ( $n=6$ mice/group). BAL fluid cell numbers are reported as cells $x 10^{3}$ with mean \pm SEM. 
Table 2

BAL fluid cell number in $A p o E^{-/}$mice at $24 \mathrm{~h}$ post-exposure after the last of 10 exposures to MWCNT-7 by either i.t. instillation or oral gavage

\begin{tabular}{|l|l|l|l|l|l|l|}
\hline Cell types & I.t. vehicle & I.t. $\mathbf{4 0} \boldsymbol{\mu g}$ & I.t. 400 $\boldsymbol{\mu g}$ & Oral vehicle & Oral 40 $\boldsymbol{\mu g}$ & Oral 400 $\boldsymbol{\mu g}$ \\
\hline Total cells & $181.8 \pm 40.3$ & $126.5 \pm 36.9$ & $157.9 \pm 18.6$ & $27.7 \pm 5.3$ & $42.8 \pm 3.2$ & $39.7 \pm 4.8$ \\
\hline Neutrophils & $13.4 \pm 4.4$ & $21.4 \pm 11.5$ & $21.0 \pm 4.0$ & $0.0 \pm 0.0$ & $0.0 \pm 0.0$ & $0.4 \pm 0.2 \dagger$ \\
\hline Macrophages & $46.6 \pm 9.1$ & $39.5 \pm 9.0$ & $58.9 \pm 8.7$ & $25.2 \pm 5.3$ & $35.2 \pm 2.8$ & $33.3 \pm 4.1$ \\
\hline Eosinophils & $90.6 \pm 23.4$ & $43.1 \pm 13.1^{* *}$ & $15.0 \pm 5.9 * * *$ & $0.0 \pm 0.0$ & $0.9 \pm 0.8$ & $0.2 \pm 0.1$ \\
\hline Lymphocytes & $30.0 \pm 10.9$ & $19.9 \pm 7.8$ & $52.5 \pm 7.1 *$ & $0.3 \pm 0.1$ & $1.9 \pm 1.0$ & $1.0 \pm 0.4$ \\
\hline Epithelial & $2.1 \pm 1.2$ & $2.6 \pm 0.9$ & $10.5 \pm 3.3$ & $1.8 \pm 0.6$ & $4.7 \pm 1.1$ & $4.3 \pm 0.9$ \\
\hline
\end{tabular}

ApoE $E^{-/}$mice were i.t. instilled once a week for 10 weeks and BAL fluid cells were collected, stained and counted. $* \mathrm{P}<$ $0.05, * * \mathrm{P}<0.01$ and $* * * \mathrm{P}<0.001$ compared with vehicle-instilled group. For neutrophils on oral exposure $\dagger \mathrm{P}<0.05$ compared with oral vehicle using rank sum post-hoc test was used. I.t. instillation of vehicle in the lungs is associated with substantially higher cell counts in BAL fluid as compared to mice that were exposed to vehicle by oral gavage $(\mathrm{P}<$ 0.001 , not indicated by symbols in the table). Results are given as cell number $\mathrm{x} 10^{3}$, and data are presented as mean \pm SEM. Statistical analyses were performed using hierarchical nested ANOVA with Fisher's LSD test. 